\title{
نقد التقدم
}

\section{عند جان جائ روسو}

\author{
بحث مقدم من متطلبات \\ الحصول على درجة الماجستير في الآداب مناب \\ من قسم القلسفة بالزقازيق
}

حسن فهز موسي مصطفي شعيب

$r .19$ 


\section{مقدمة}

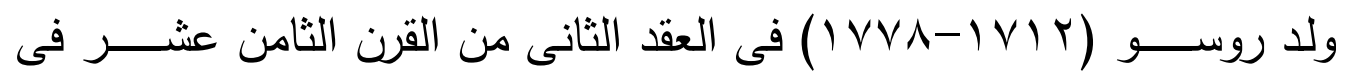
مرحلة بدا فيها نور التنوير يخبو وعناصـر الرجعية الرومانسـية تزدهر، وكان ميلاده ثمرة زواج تعس، فهو كمـا يقول (ثمرة حزينـة) لعودة حياة زوجيـة كانت قد انقطعت بهجران ابيه لامه، وقد ولا ضـعيفا مريضـا، وقد دفعت امه حياتها ثمنا لميلاده الذى كان كما يقول (فاتحة تعاسـته). ورباه ابوه الارمل الذى كان يرغمه على القراءة طوال الليل، فى قصص الرومانسـية، وقد طبعته تللك الكتابات الرومانسية بطابع لم يمحى ولى طوال حياته. لقد شـكلت فيه ذكاء خاصـا واعطته انطباعات عجيبة ورومانسـية عن الحياة، تلك الانطباعات لم تستطع التجربة والتأمل أن يشفيه منها كما يقول (روسو)، وقد انعكست هذه الرومانسية على كل كتاباته، على مفهومه للإنسـان الخير بطبيعته الذى افسدته التتظيمات الاجتماعية، وعلى نظرته لذاته (ان لم اكن افضل فإنني على

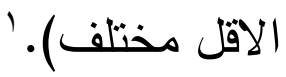
وعانى فى السـنوات الاخيرة من حياته من عقدة شـعور بالاضطهاد، ولابد انه

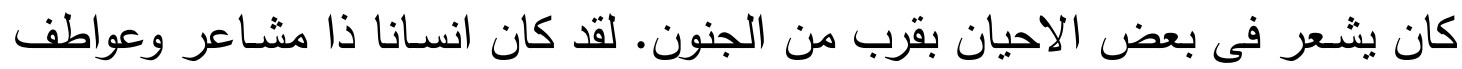

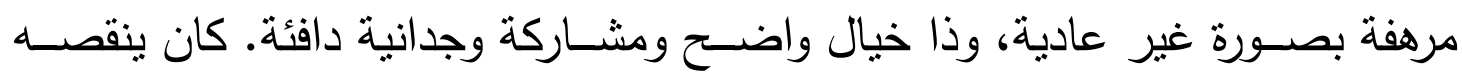

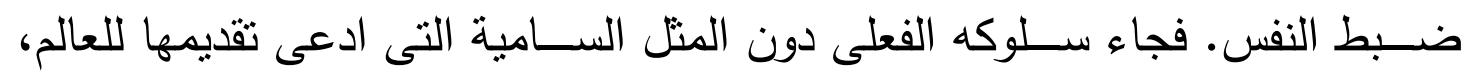
والتى آمن بها بإخلاص. ومن الصفات التى تشفع له الامانة التى جعلته يعترف فى كتابه (الاعترافات) بضعفه وعيوبه ويغالى فيها.

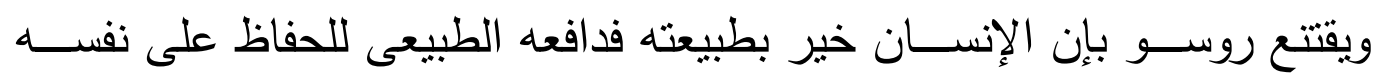

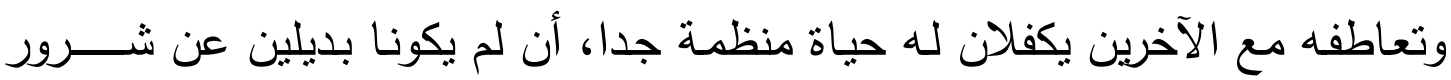

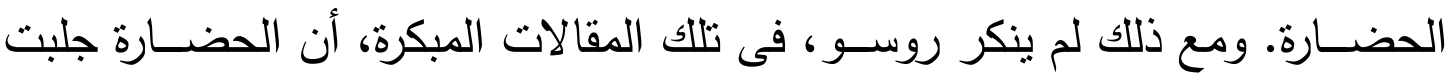
بعض المنافع، غير انه لا يجد طريقه عقلية للمحافظة على القيم واستئصـال الثـرور فى حياة مشتركة. لقد كان يرغب فى تحسين احوال المجتمع، غير انه لم يعرف كيف له 
يحدث ذللك. والنتيجة النهائية لتلك الاعمال هى اثارة عدم الرضـا بالنظام الاجتماعي،

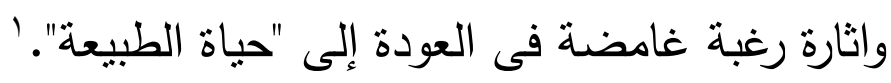

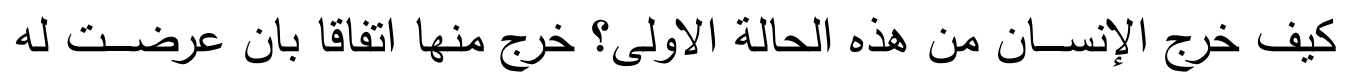

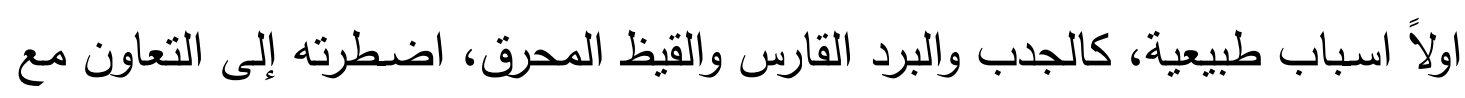

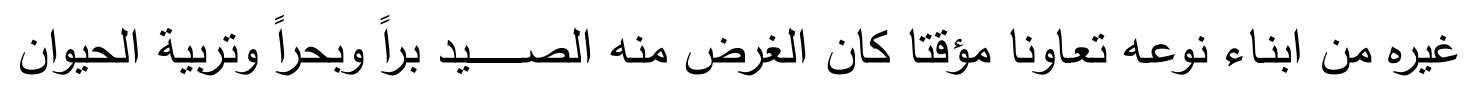

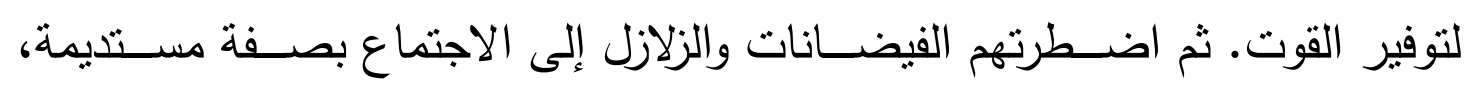

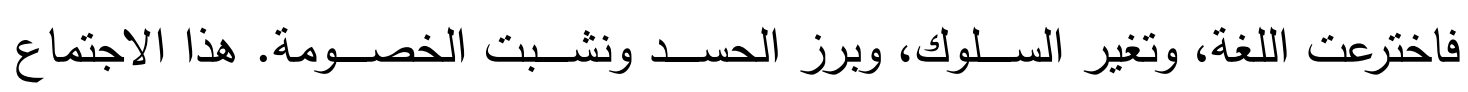

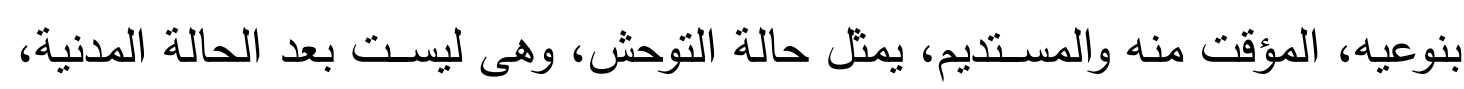

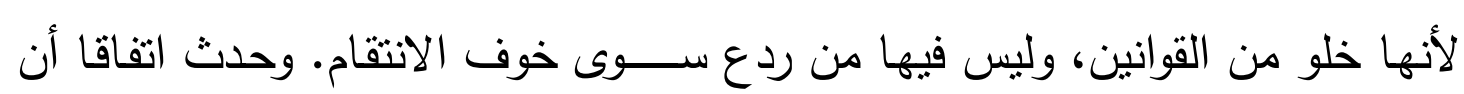

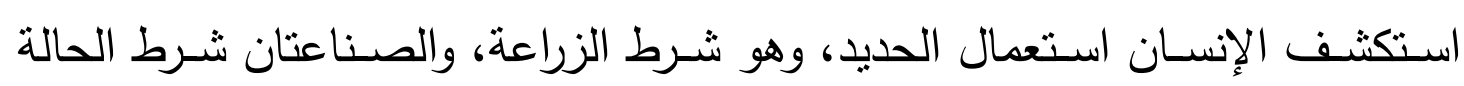

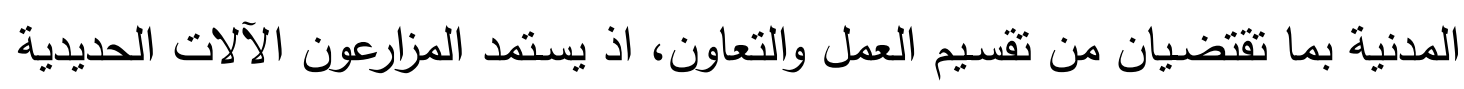

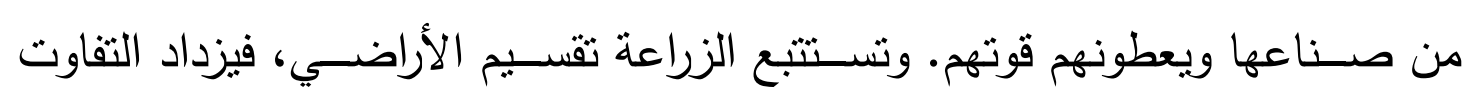

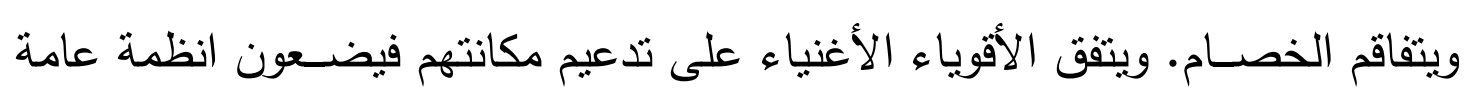

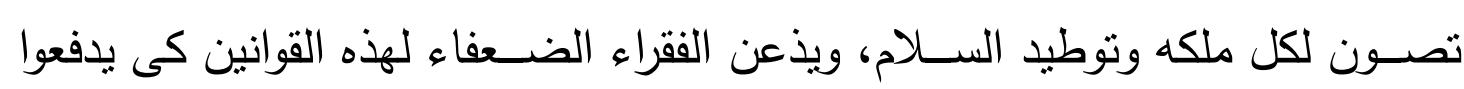

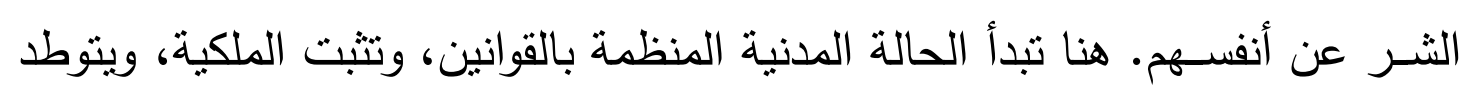

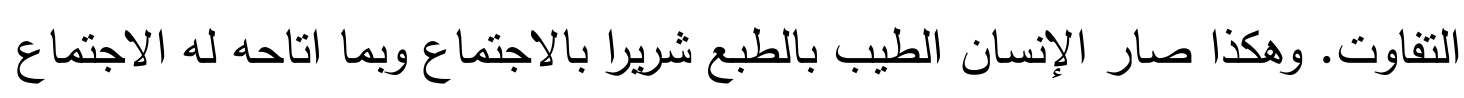

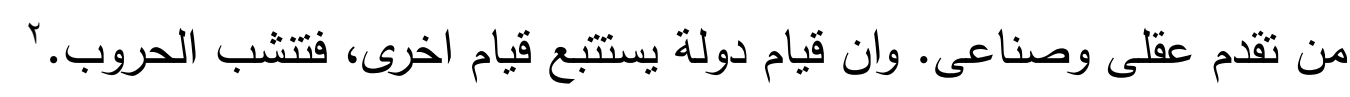

وتثــبه آراء روسـو فى الدين آراء فولتير ومؤلهة طبيعيين فرنسـيين اخرين.

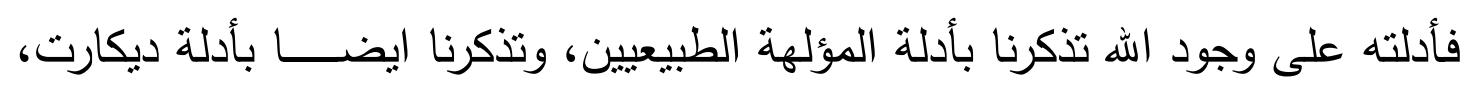

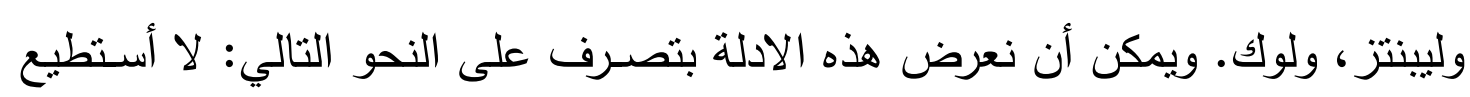

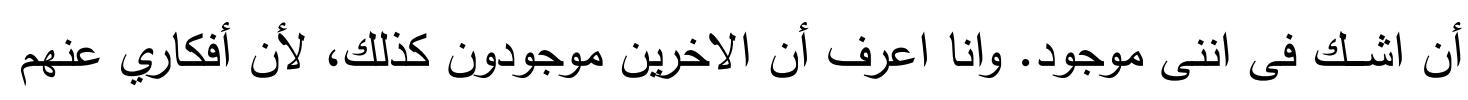

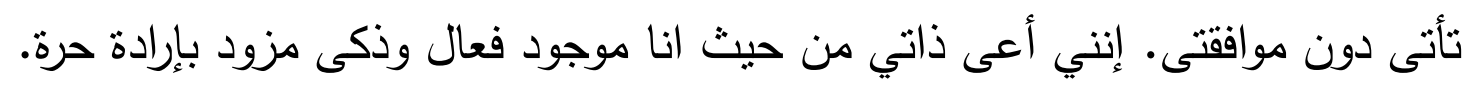

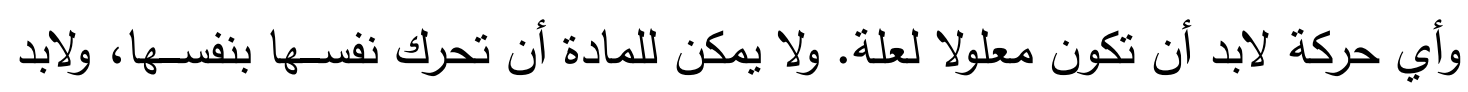


أن تكون هنالك إرادة تحرك الكون وتحرك كل مادة، وأعنى بها الله. وبالتالي يكون اله موجودا، ذا عقل، وقوة وارادة. غير إنني لا أســنطيع أن اكتشــف ماهية الله، ولا أقدام ادلة اخرى عليه غير الادلة التى اضطر لتقديمها من جهة ما يظهر لنفسي. ويحافظ الله على الكون وفقا لقوانين الطبيعـة، ولا يقوم بمعزات تخالف هذه القوانين. وليس

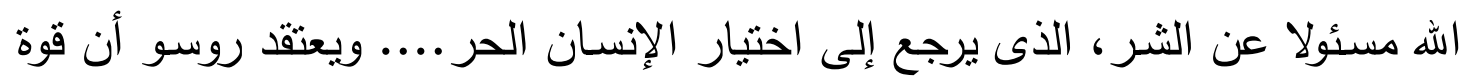

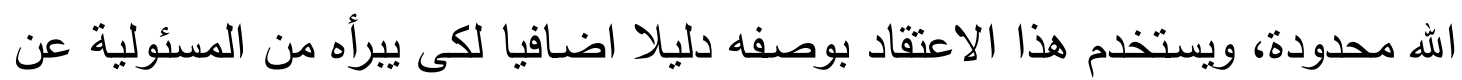

\section{روسو ضد الحياة المدنية:}

هاجم روســو الحضــارة وعارض بين العقل والعاطفة، وزعم أن التفكير يتلف

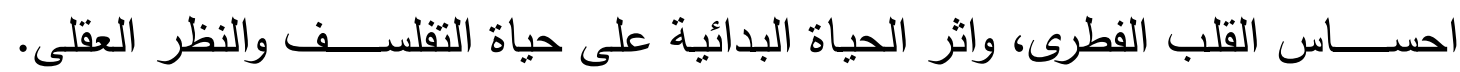
والإنسان عنده خير بفطرته ، يفسده التفكير ، وتتلفه الحياة الاجتماعية.

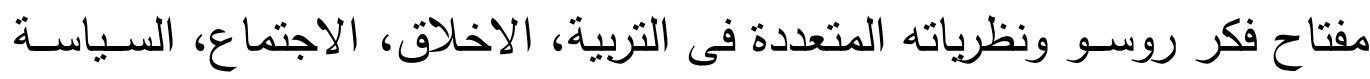
هى هذه العبارة. (كل شئ يخرج طيباً من يدى الخالق، ويفسد بيد الإنسان).

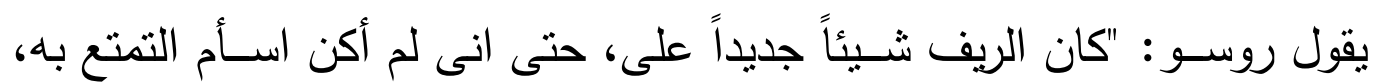
وقد شعرت حياله بحب بلغ من حيويته انه لم يخمد قط". وسيستقر هذا الذوق فى نقس روسو، ويلازمه، ويكون احدى صساته الجوهرية: سيواجه دائما بساطة الريف بفساد الحضر .

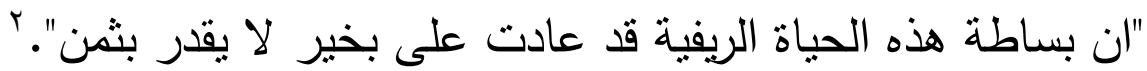

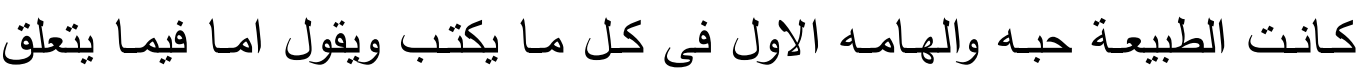
بشـــــــــه فهو (طبع حاد، وعواطف حية جامحة، وافكار بطيئة التولد، مرنبكة لا لان تحضـرنى الا متاخرة، حتى لكان قلبى وذهنى ليسـا لثخص واحد ـــ فالثـعور ، وهو

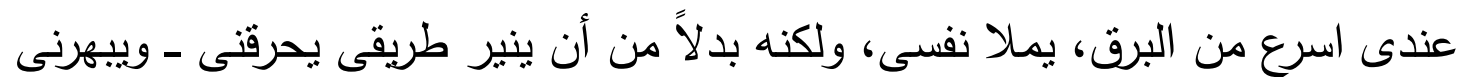
هذا البطء فى التفكير ، المقترن بهذه الحيوية فى الثــــور ، لا يعترينى اثثاء الحديث 
فقط، وانمـا يلازمنى فى وحدتى واثتـاء عملى، ذلك أن أفكاري تتنظم فى رأســي

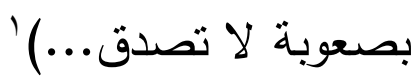

كتب روســو رســالته بثــجاعة، وكانت آراؤه مبتكرة حديثة، فكتب ضـــــ العلوم والفنون والآداب، وضـــ المجامع العلمية نفسـها، فنال جائزة المجمع العلمي بديجون، مع انه كتب ضده، واخذ يهزا بأسلوبه الأدبي القوى بالغنى والثروة، والترف والحضـارة والمدنية، وقال انها أصل الرذائل وفساد الاخلاق. وكانت كتابته مملوءة بالقوة والحرارة والعاطفة، خالية من المنطق والترتيب المنطقي. والحق أن هذه أضـــعف رســالة من ونـ رســـائله إذا فكرنـا فى المنطق والترتيب والنظام. ولا عجب فهو حديث فى الكتابة، والكتابة فن لا يستطيع الإنسان أن يجيده مرة واحدة.

وبمعارضــــته الرأي المعروف وهو أن للعلوم والفنون والآداب كل الأثز فى إصـاحح الأخلاق وتهذيبها اظهر قوته وذكاءه وقدرته على الابتكار والافتتان. تحتوي هذه الرســالة على اصــول مبادئه وآرائه وعقائده التى اظهرها فى كتبه المختلفة فيما بعد. ومن تلك الآراء تعرف اخلاق روســو، وعداءه للتقاليد العادية، والترف والمدنية، والمظاهر الاجتماعية، ونظام الطبقات وعداءه لمن يعتدى على الحرية.

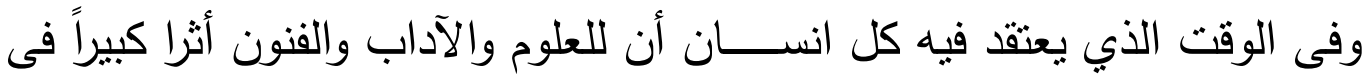

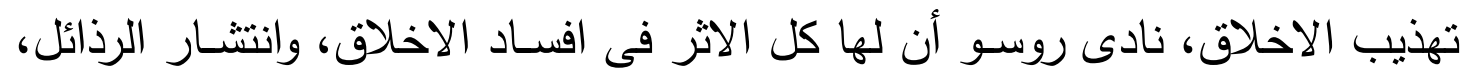
فناقض نفسـه بنفسـه، فهو بالعلم والادب والفن ارتقى، وارتفع من الحضـيض ووصـل إلى القمة، ولم يرجع إلى الوراء.

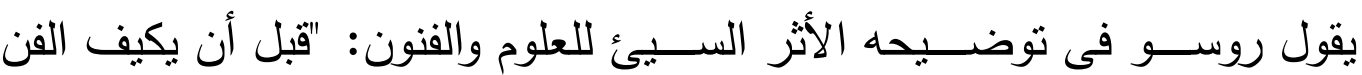
سـلوكنا ويعلم عواطفنا التحدث بلهجة مصــطنعة كانت اخلاقنا ريفية غليظة، ولكنها طبيعيـة... امـا اليوم، وقد جعلت الابحاث البارعة والذوق الرفيع من فرط الاعجاب مبادئ، فتسـود اخلاقنا وحدة وضـيعة خادعة، ولم يعد أحد يجرؤ على الظهور على جلى 


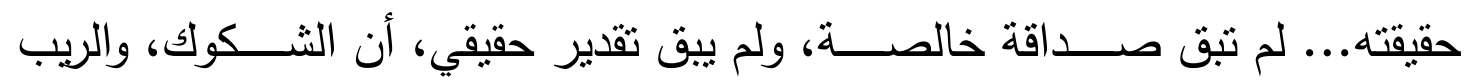
والمخاوف، والتحفظ والحقد، والخيانة... سوف تختفي دائما تحت قناع الادب الزائف. إن الانحلال لأمر واقع، وما تقدمت العلوم والفنون يوما إلا وافسدت نفوسنا".

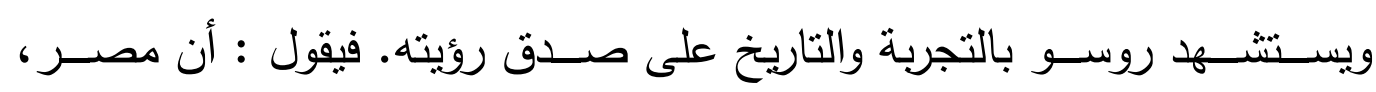
اليونان، الرومان، الصين كانت صافية وجميلة ثم اصابها الترف والانحلال والعبودية التهانية

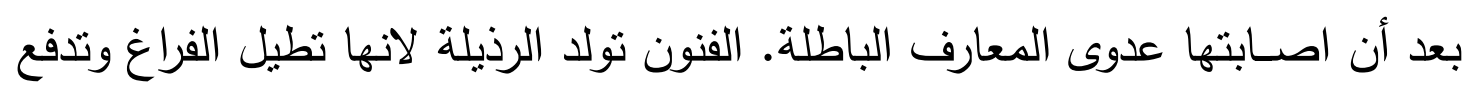

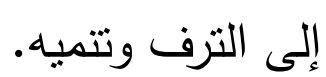

والعلاج الوحيد لهذا الفـــاد هو التخلى عن المدنية، والعودة إلى الطبيعة، التى هى المدار والبؤرة التى يشع منها فكر روسو الفلسفى.

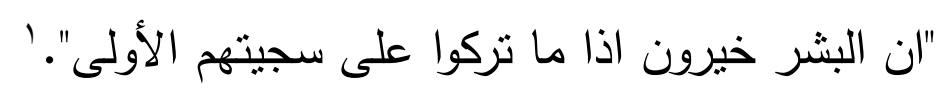

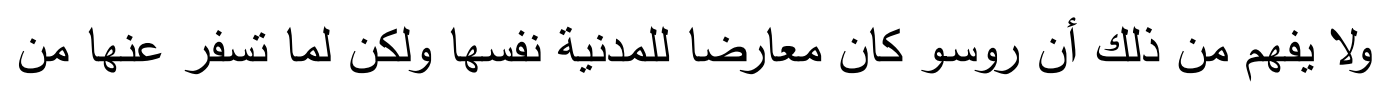
نتائج شريرة. فى عام Vo Vo كتب روسو رسالة عن (اصل التفاوت بين البشر)، فصل فيها

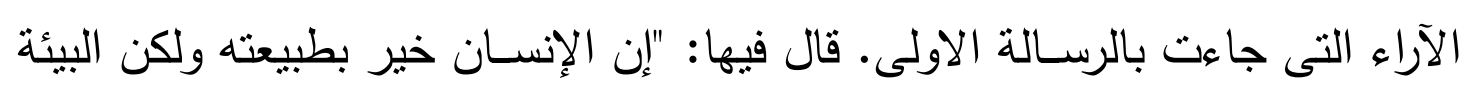

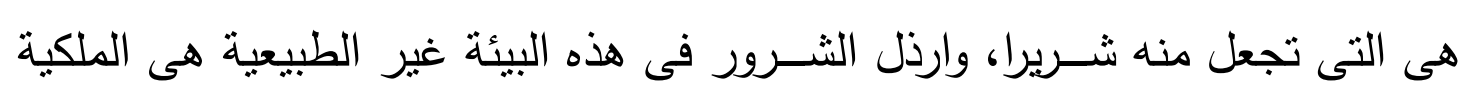

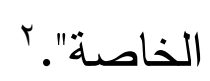

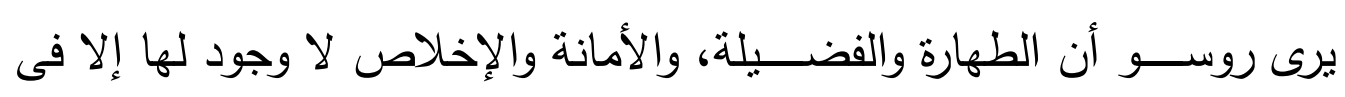

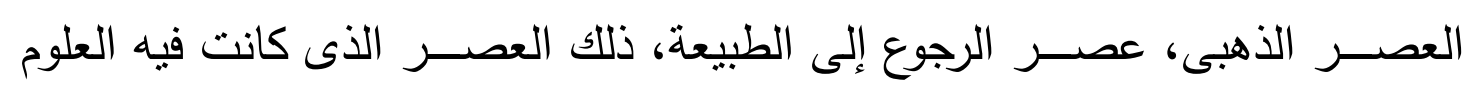

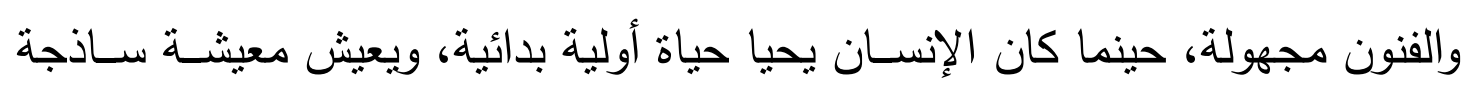

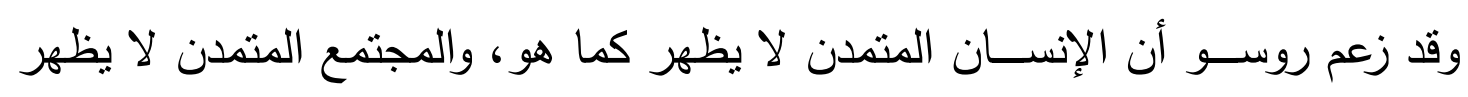

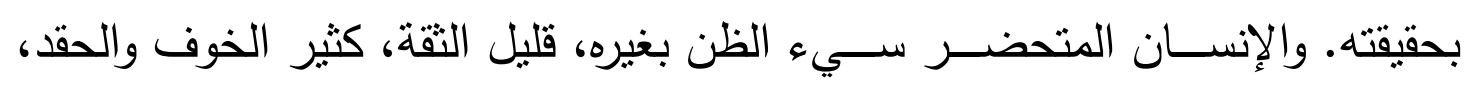
كثير البغض والخيانة، ويخفى هذه الصفات كلها فى نفسه، ويتظاهر بالأدب والثقافة

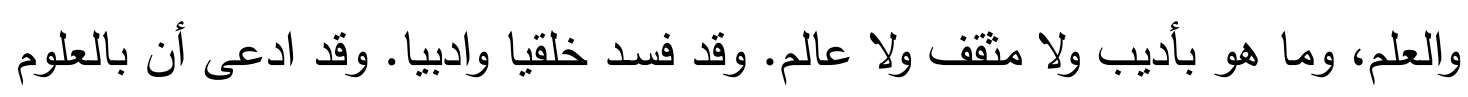

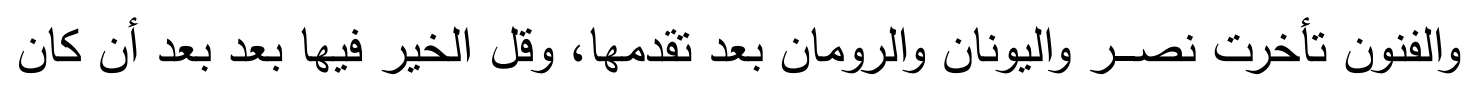


كثيرا، وانتـــر الثــر بعد أن كان قليلا، وبدت بها علامات الضـعف والخلاف، وقد

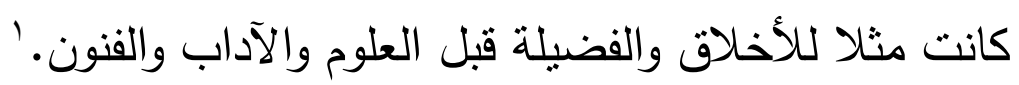
والادب ذاته عنصر من عناصر الفناء: يحكى أن الخليفة عمر حين ســـل فى أمر مكتبة الاســـكندرية وما يفعله بها أجاب: "واما الكتب التى ذكرتها فان كان فيها ما يوافق كتاب الله ففى كتاب اله عنه

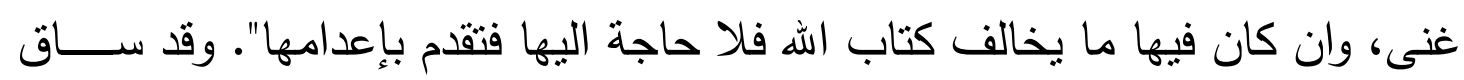

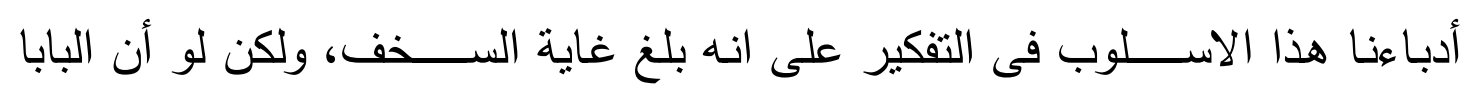
جريجورى الاكبر كان فى مكان عمر ، والانجيل فى مكان القران، لاحرقت المكتبة رغم ذلك، ولربما عد هذا اروع عمل قام به فى حياته. انظر إلى تاثير الفلســفة الممزق فبعض (محبى الحكمة) هؤلاء يخبرونتا بانه فئه

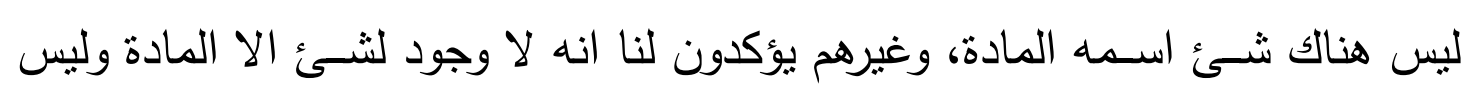

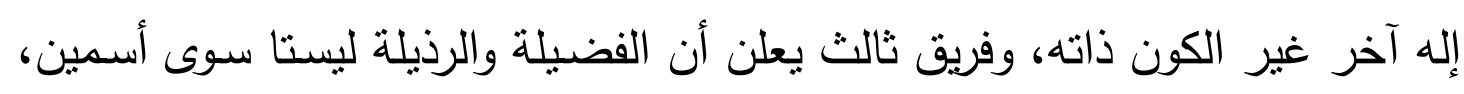

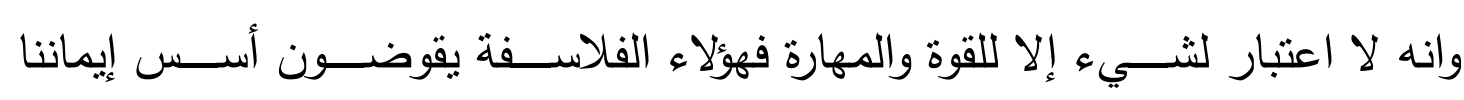

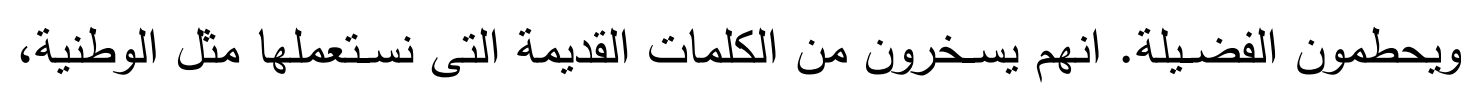

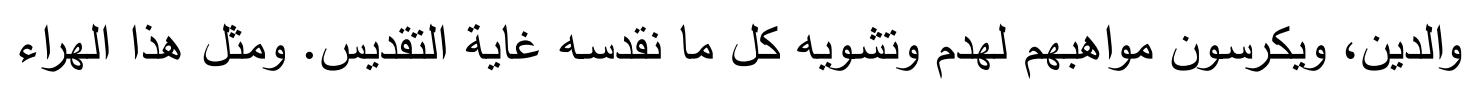

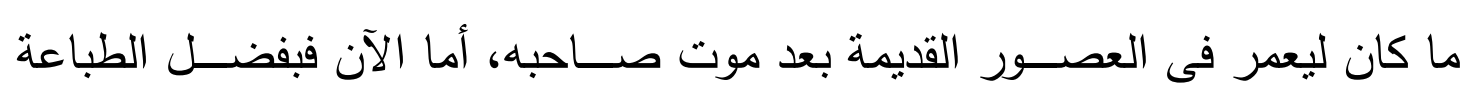
ستنقى إلى الابد تأملات هوبز وسبينوزا المؤذية.

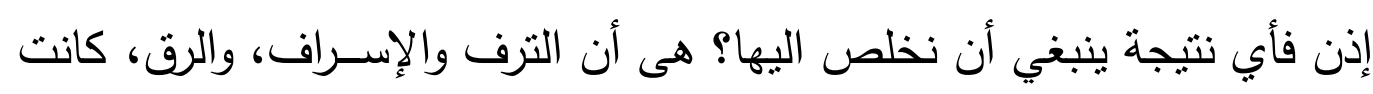

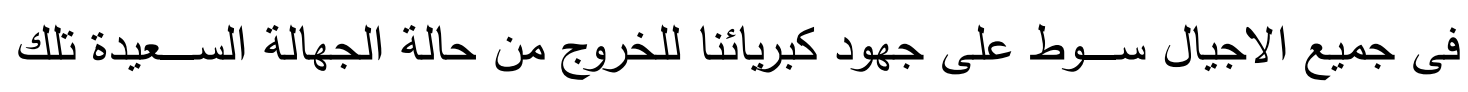

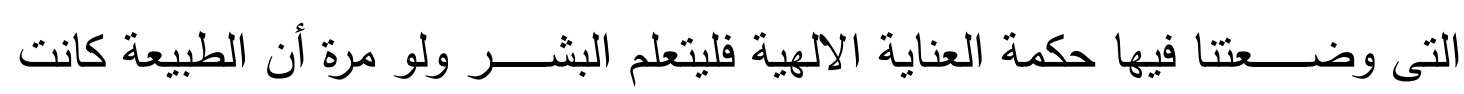
تحميهم من العلم، تماما كما تخطف الام سلاحا خطرا من يدي ولدها.

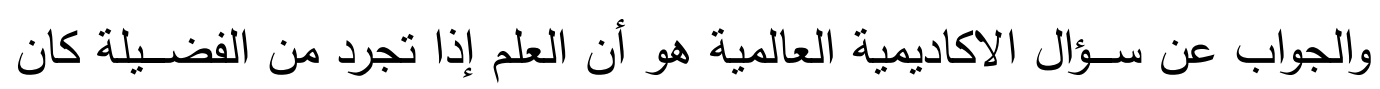

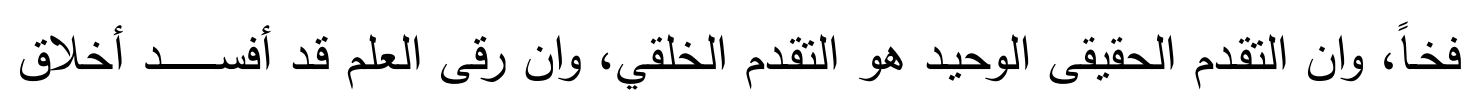


البشر أكثر مما طهرها، وان الحضـارة ليست ارتقاء الإنسـان إلى وضــع أسـي، بل سقوطه من بساطة ريفية كانت فردوس البراءة والسعادة.' روسو والهجوم على المسيحية:

ينطلق هجوم روسو على اية صفات خارقة يحاول القساوسة ادعاءها كالالهام والوحى. فهو وان كان يعتقد فى المســـيحية إلا أنه يرفض الاعتقاد فى الكنيســــة كمحمة لله فى الارض، ومن ثم تكون لها سلطة إلى جانب سلطة الدولة. يقول روسو : أن المسيحية كيان روحانى صرف لان تعنى إلا بالأمور السماوية،

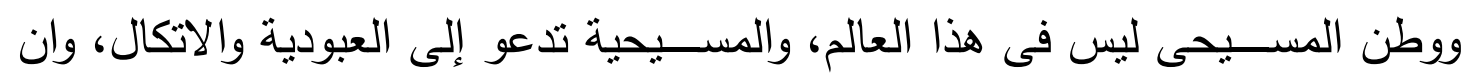

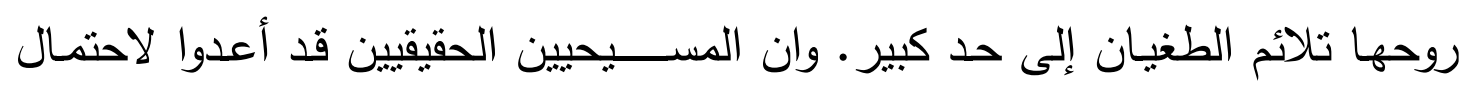

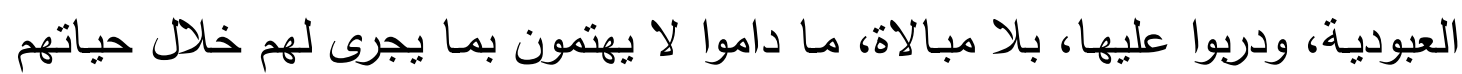

$$
\text { القصيرة على الارض." }
$$

ويذهب روسـو إلى القول بان المسـيحية ضـــارة بالأمة، وفضــائلها هى ذاتها

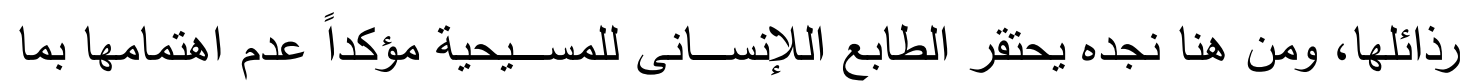
هو دنيوي، لأنها تمنع أي ازدهار حقيقى للروح الحربية أو النضالية. لذلك لابد من استبدال المسيحية بديانة أخرى قادرة على استيعاب البعد القومى التى التهاري

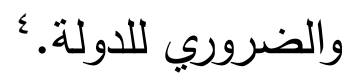

من هنا دعا روسـو إلى دين مدنى اجتماعى يفصـل به بين الســلطة الدينية والسلطة السياسية على نحو ما فعل اسبينوزا وهوبز من قبل.

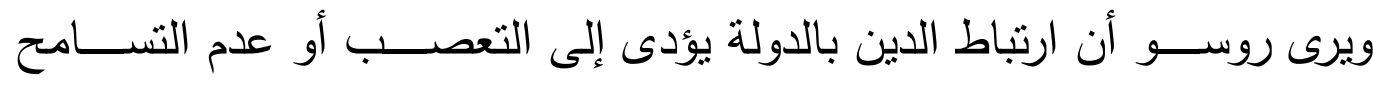

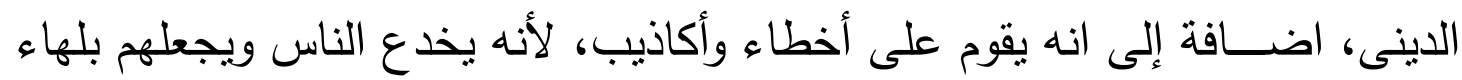

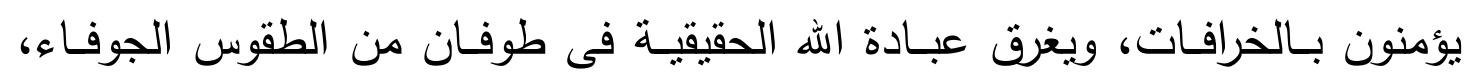
فيجعل الشعب لا يتتفس إلا القتل والدذابح.

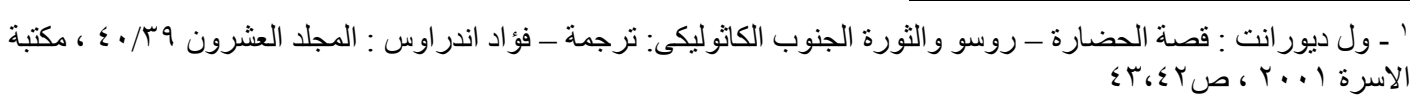
Hill, Crislopher : Hobbes.T.and the Revolution in political thought.ed.by.jidith N .shklar.Macmillan - ${ }^{r}$ Company.N.y.1968.p.39 Rousseau.jj: the social Contract. Trns by . colo .D.H.N.y.1950.p.136 - ${ }^{r}$ ibid :138 - 
ولا ييقى بعد ذلك سوى دين الإنسان أو المسيحية. المسيحية ليست كمؤسسة أو كنيسة، وانما مسيحية الانجيل التى تختلف عن المسيحية الاولى تماما. بمقتضى هذا الدين المقس السـامي الحقيقى، يعترف الناس، وهم جميعا احباء

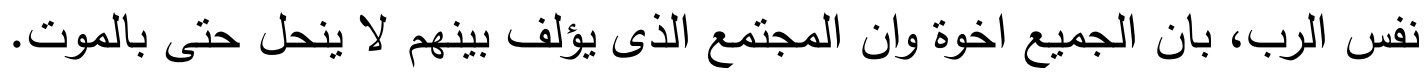

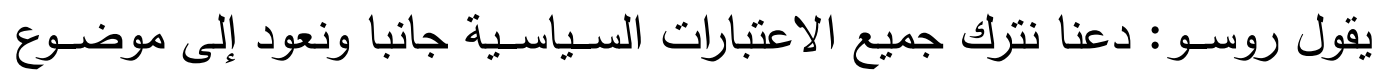

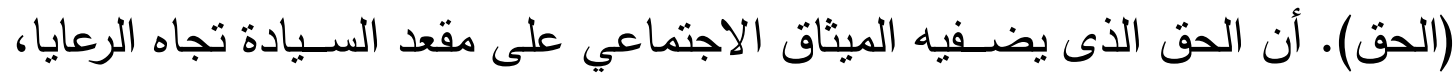

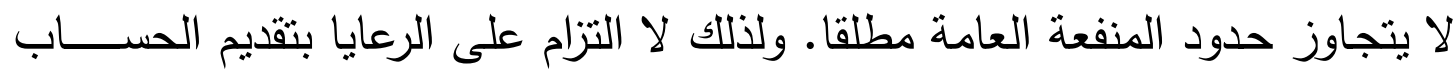
إلى مقعد السيادة عن آرائهم إلا فى حدود كون هذه الآراء تهم المجتمع.

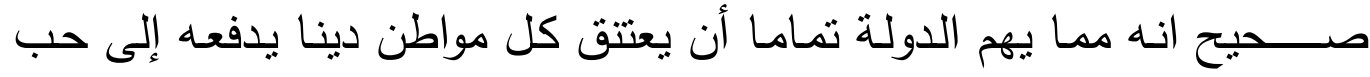

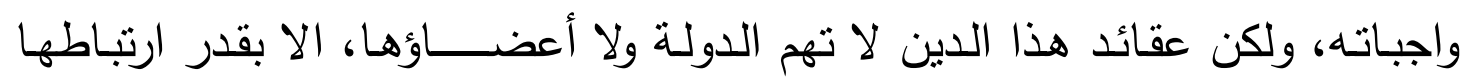

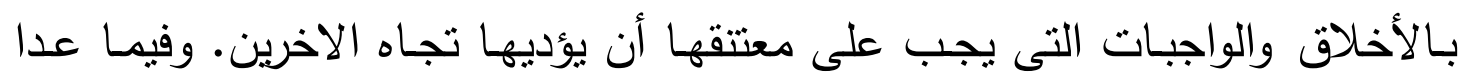
ذلك، فان كل مواطن له أن يعتقق ما يثاء من الآراء.

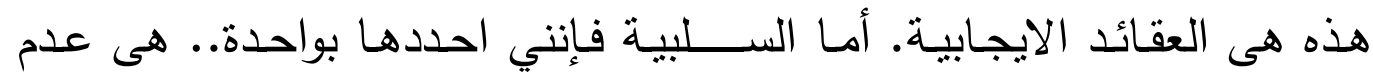

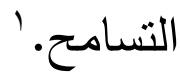
هذا هو الدين الددني الذى اقره روســـو والذى دافع به عن الايمان بالهه وحقوق

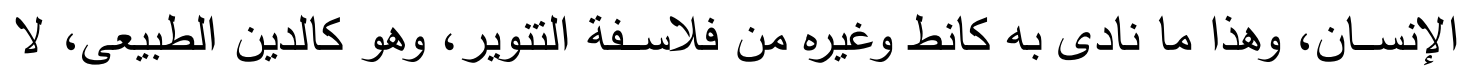
يعد دينا سماويا قائما على الوحى، وانما هو دين يستمع إلى صوت القئ القلب كما يرتكز

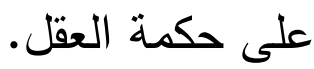

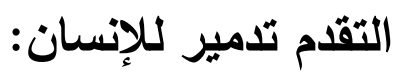

أن الانقلاب الاكبر في حياة الناس قد نجم عن انتتــــار الزراعة، واكتتــــاف

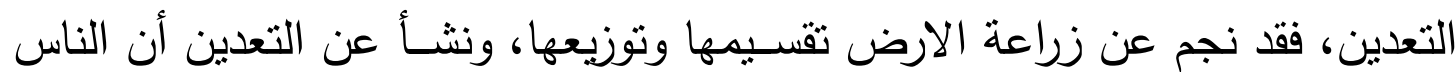

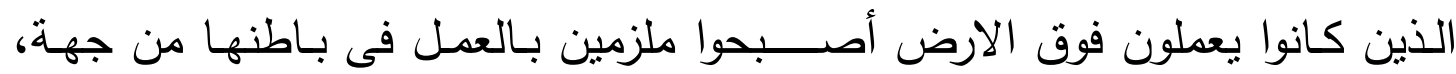

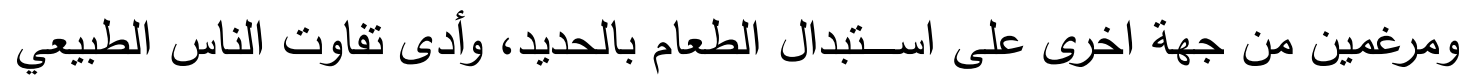

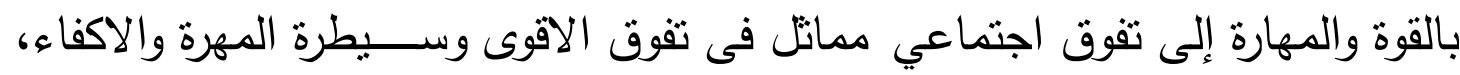

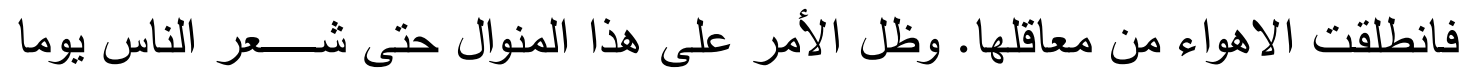

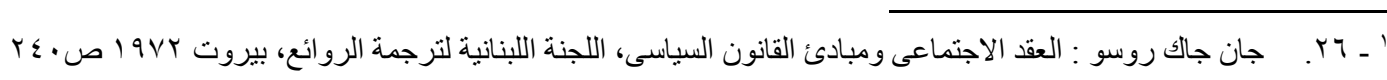


بأن مصلحتهم الخلاص من هذه الفوضى، ووضع حد لها، فقبدوا بقيود الحق ما كان مكتسـبا بالقوة وحدها، واصـطلحوا عندئذ على تثبيت القوانين وتتظيم المجتمع وهكذا،

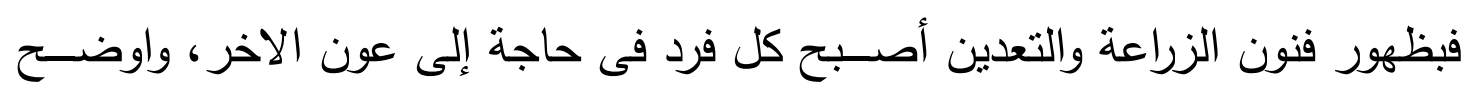
التعاون بين الناس أن بينهم تفاوتا فى المهارة والقوة، فحظي الاقوى منهم بكمية أكبر

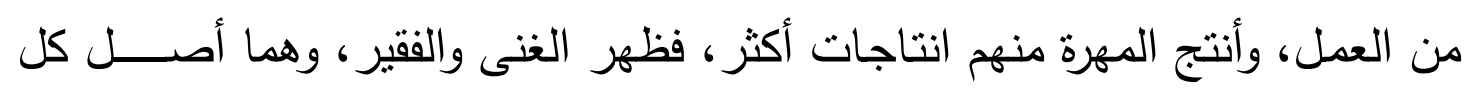

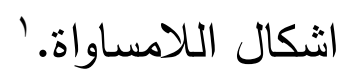

ان روسو يدعونا إلى العودة إلى الطبيعة، فلقد اوضسح روسو فى كتابه (اميل أو

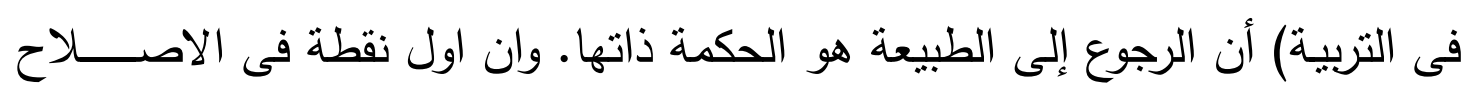

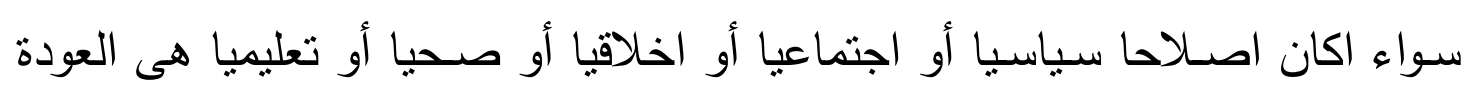
إلى الطبيعة واتباع قوانينها. أراد روســو أن يجد اســلوبا تربويا يحفظ على تلميذه (اميل) خصــــال البراءة

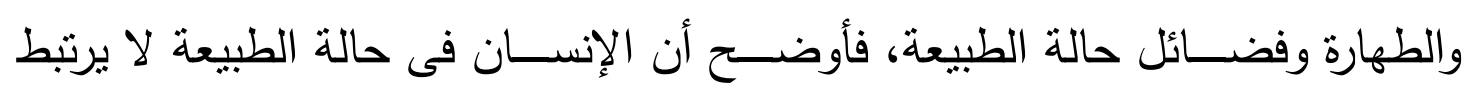

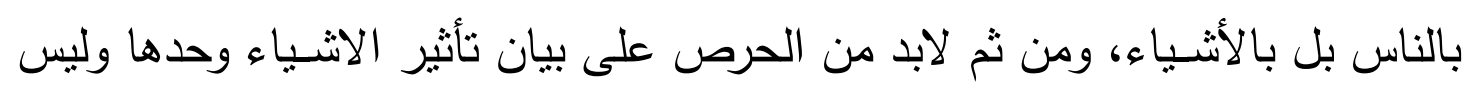

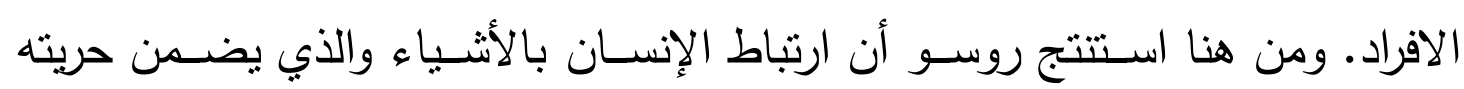

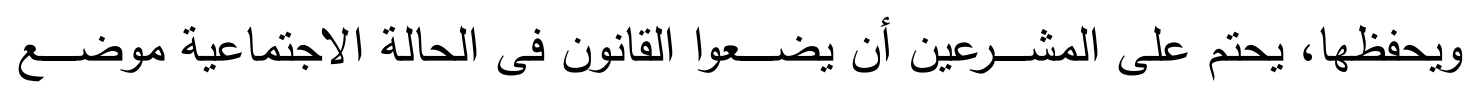

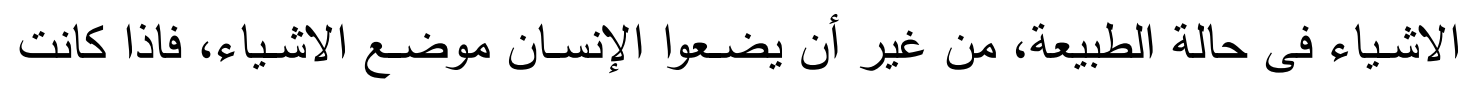

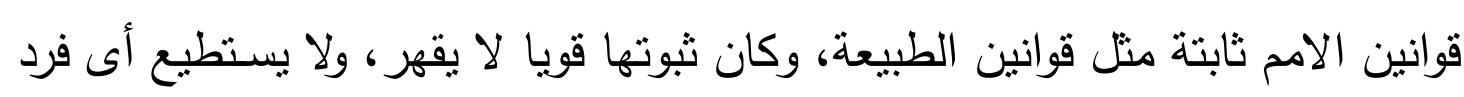

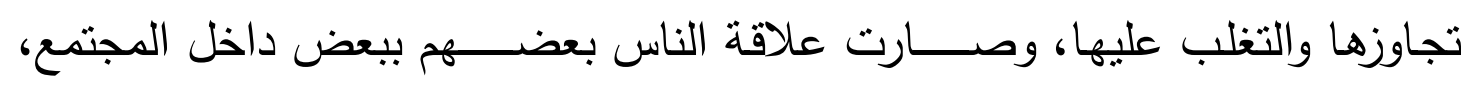
كعلاقة أحدهم بالأشـياء فى حالة الطبيعة، وهذا يعنى تحويل الإرادة الخاصــة للأفراد إلى ارادة عامة واحدة تعلو على ارادات الافراد.

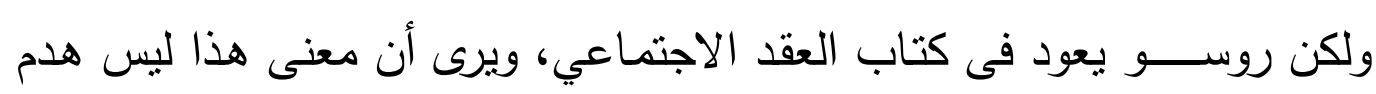

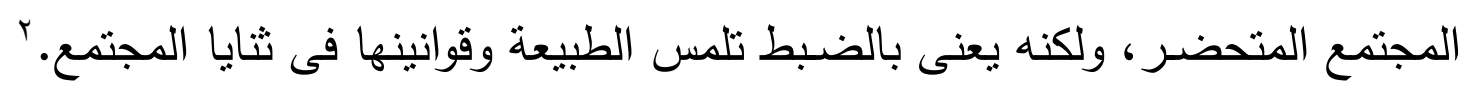

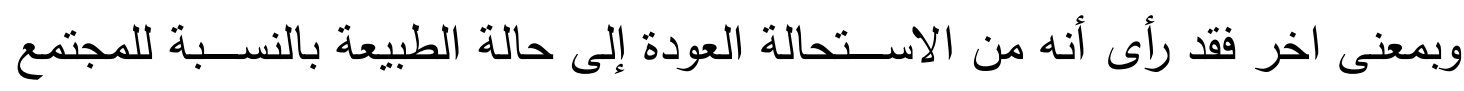

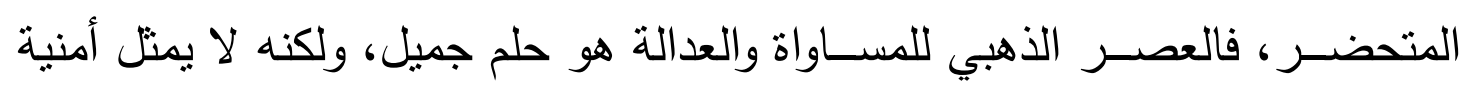


قابلة للتحقيق، ومع ذلك يمكن أن نعتبر حالة الطبيعة كمعيار ثابت تصحح عن على

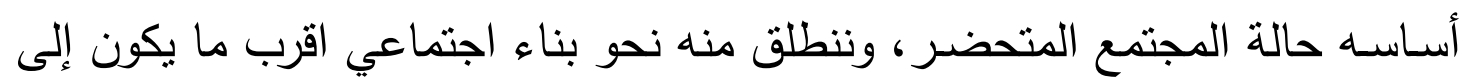
السلامة.

\section{التقدم والتتوير والاغتراب عند روسو:}

قام عصـر التتوير على أفكار أســـــة تتعلق بالعقل والطبيعة وتعلقت بأهم

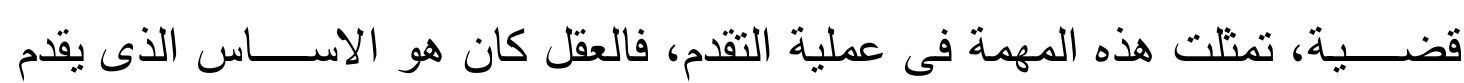

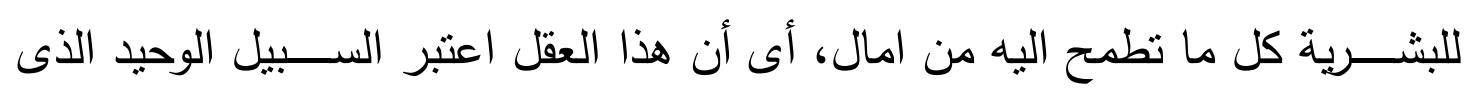
يمكن الإنسان من السبطرة على الطبيعة وذلك عن طريق العلم. لقد عجز الإنسـان امام كل ما كان يؤمن به فيما مضسى (مدينة الله) فى السـماء

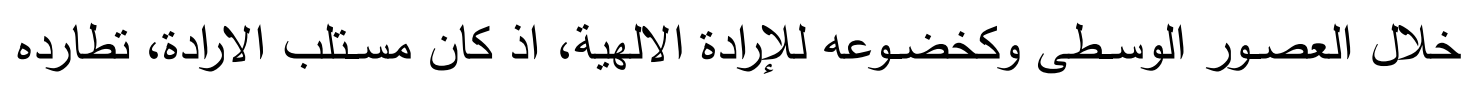
الامور الدينيـة الغيبية فى كل مكان، لذلك حاول مفكري عصـــر "التتوير" اخراج الإنسـان من حياته البائسـة تلك، ولن يتحقق ذلك الا "بإعطاء تفسيريرات جديدة عقلية للإنســـان ولكل ما يحيط به حتى يكون محوراً لعملية التقدم ومحوراً للحركة التاريخية

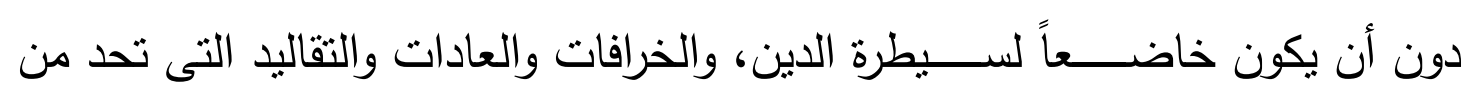

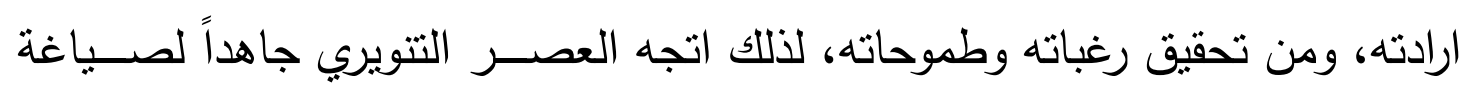

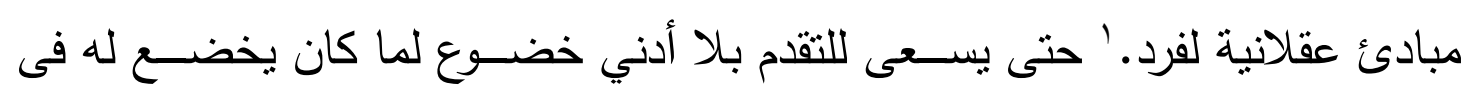
السابق وخاصة السلطة الدينية.

لقد ارتبط مفهوم العقل انذاك بنبذ الخرافات والاساطير أو بنبذ التقافات السابقة

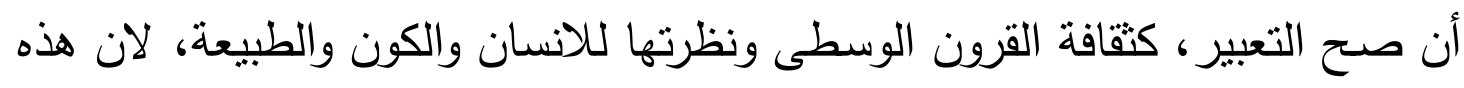

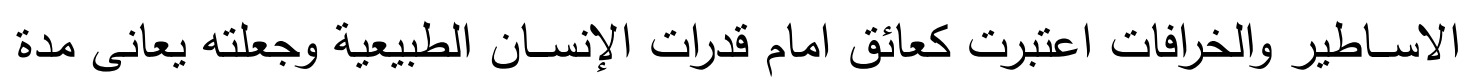
طويلة من الزمن، من كل معالم الجهل والظلام، وانطلاقا من هذا كانت ارادة فلاسـفة الإنة

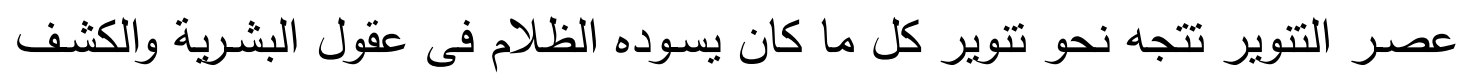
عن الاقنعة المزيفة التى كان برتديها رجال الدين. 
ويتمثل التقدم فى تقدم العلوم والمعارف وفيما يؤدى اليه هذا التقدم كالتحكم الإنساني فى الطبيعة والسيطرة عليها حيث أصبح التفسير المفضل لدى المتقفين فى الصى

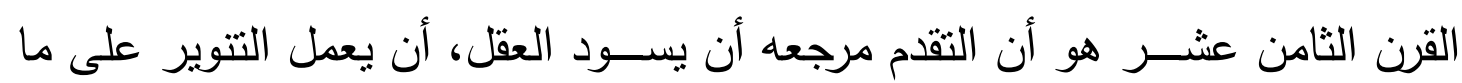

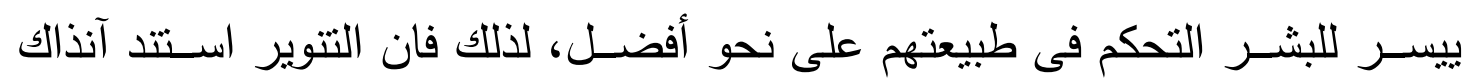
على فكرة غزو الطبيعة والسيطرة عليها.

يبدو واضــــاً اكثر الربط التاريخى بين التقدم العلمى والتكنولوجى، وبين فكرة التقام بالمعنى الأخلاقي والنقافي مع القرن الثامن عثـر اذ كانت مجهودات العلماء

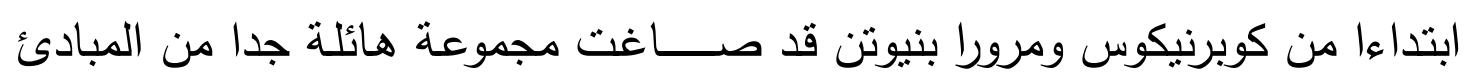

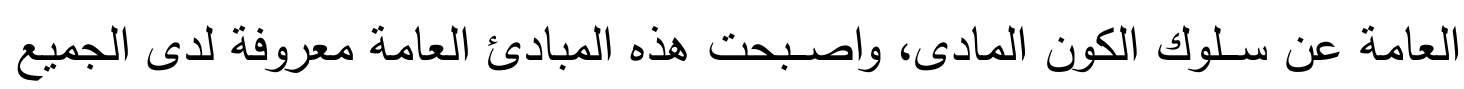

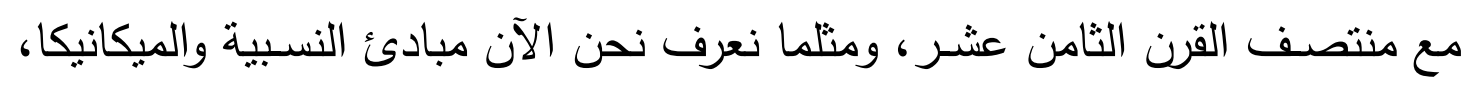

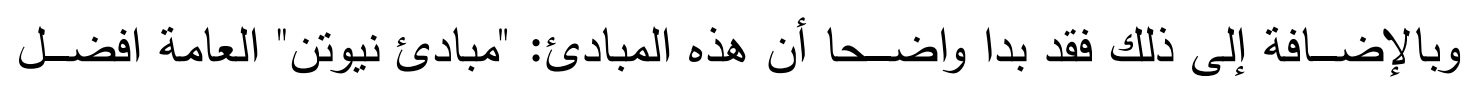

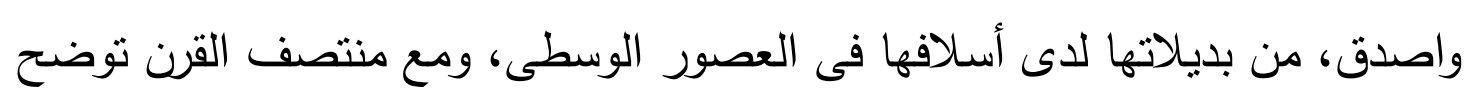

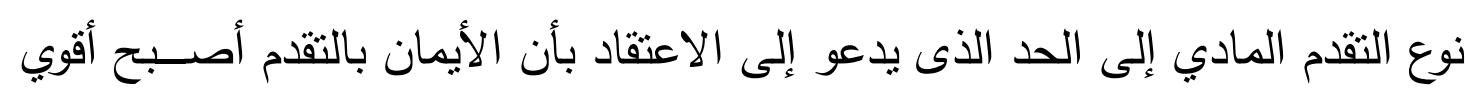

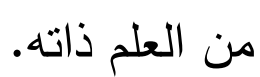
لقد غدا طموح البشرية الآن يتلخص فى أن يصبح أفضل وأسعد، وأقرب إلى الى الفي

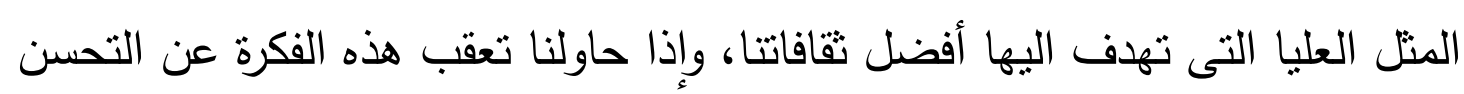

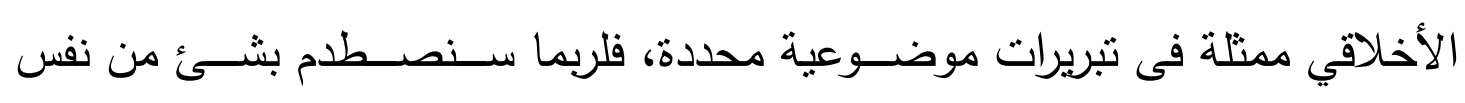

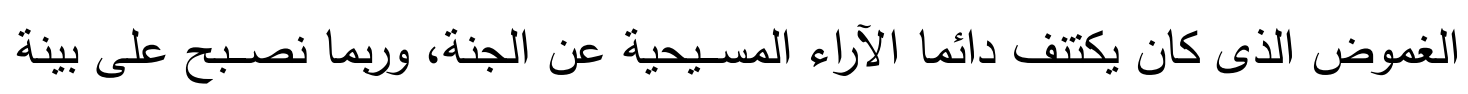

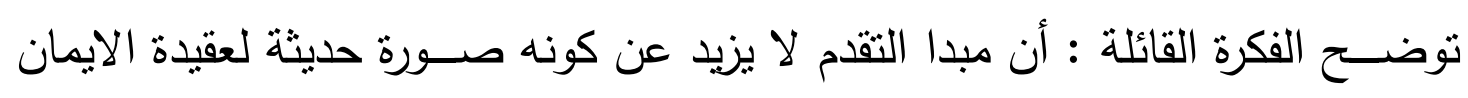

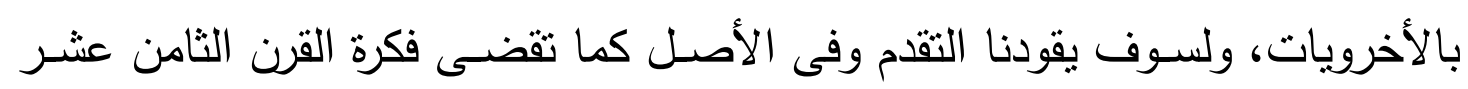

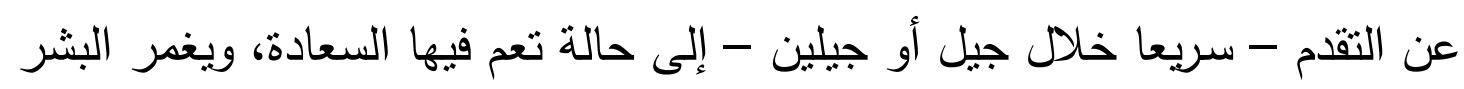

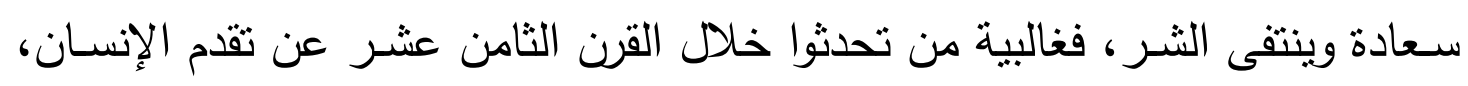

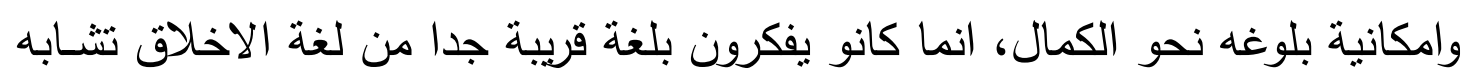
لغات الاخلاق الدينية التى كانت تبثر بالسلام على الارض.

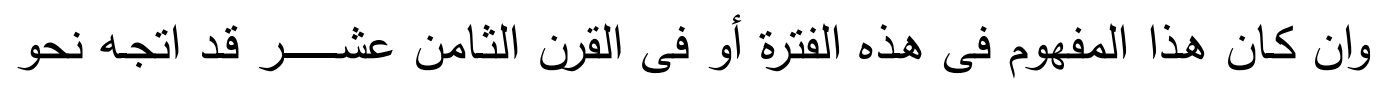

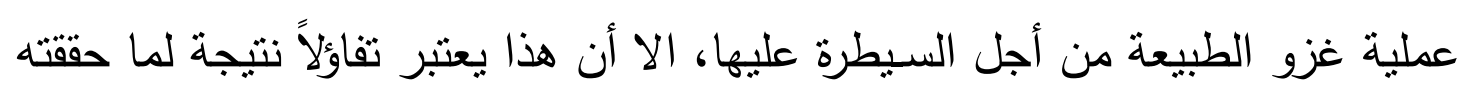


العلوم الطبيعية من نجاح كبير خلال القرن السـابع عثـر، ونجاح تطبيق هذه العلوم

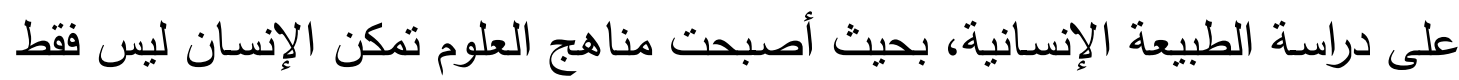

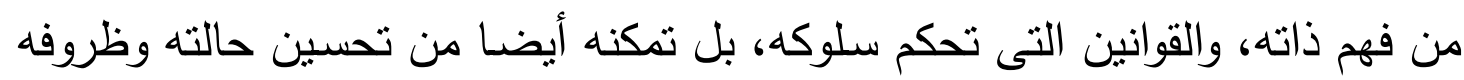
الإنســانية عن طريق محاولة الســـادة والســـيطرة على الطبيعة الداخلية والخارجية

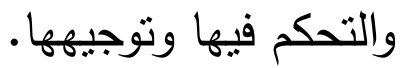

كما ارتبطت الفكرة الاساسية عن التتوير كذلك بروية "آلية" وبروئة اكثر مادية

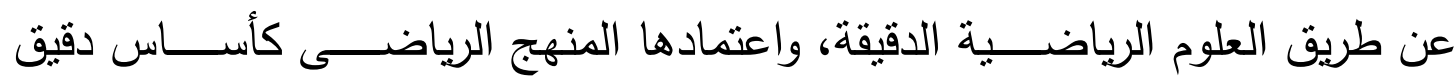

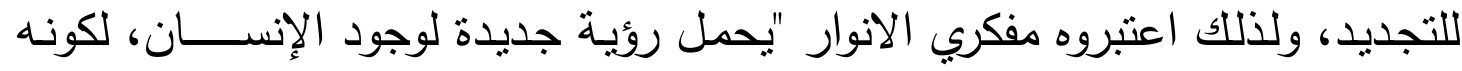

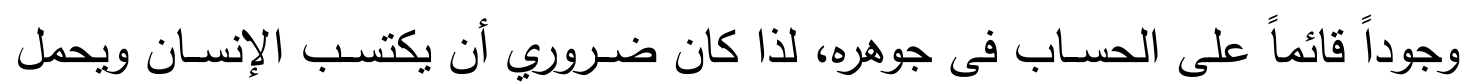

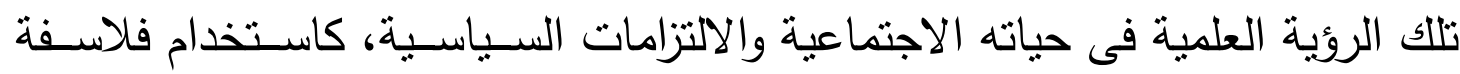

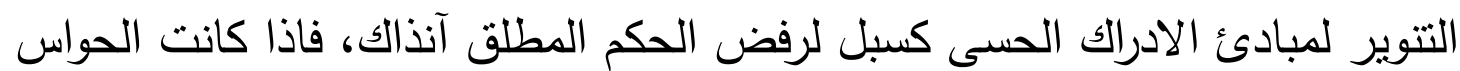

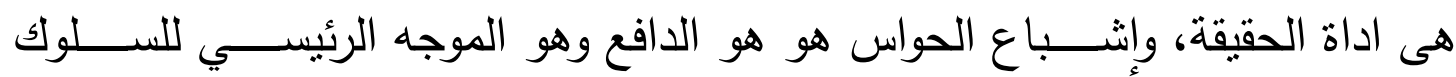

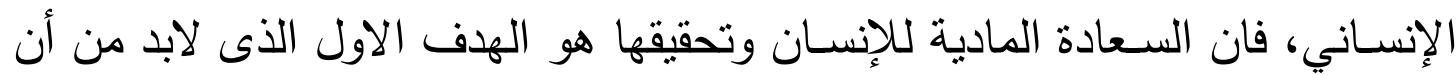

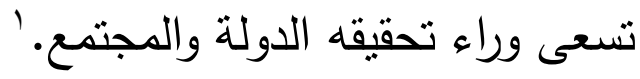

الثشئ الأسساسي الذى يلفت انتباهنا هو موضوع الطبيعة البشرية، فكرة الطبيعة

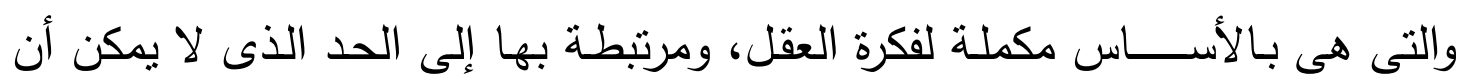
نفصـل بينهما، حيث أن الطبيعة تعنى.. مجموعة الاثـــياء المحسـوســة المرتبطة ببعضــها، كمشكلة الكون أو العالم المادي الذى يسير وفق قوانين منظمة ومتتاسقة،

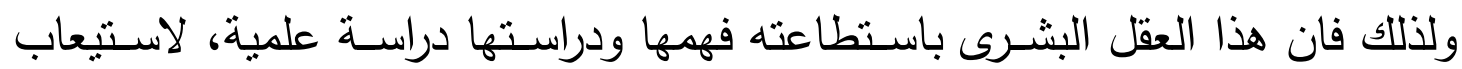
قوانينها العامة. † ولقد كان هلفيتيوس اكبر فيلســوف مادى فرنســي فى القرن الثامن عشر ، يؤكد أن التطور المعرفي مشروط بقوانين، اذ يستتد على اسباب معينة محددة،

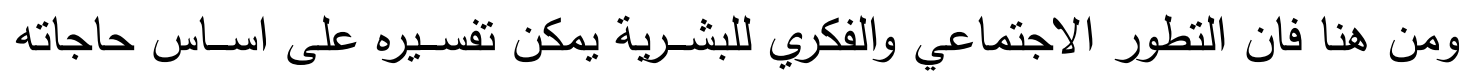


المادية ، ' اعتبرت هذه المحاولة من هيلفيتيوس، وان لم تلقى نجاحا الا انه حاول

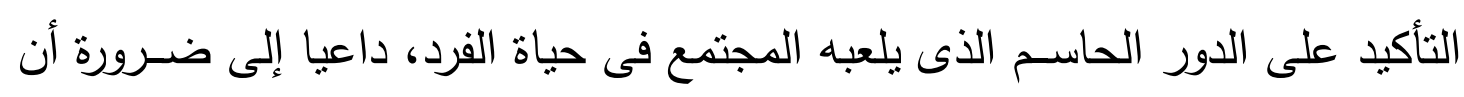

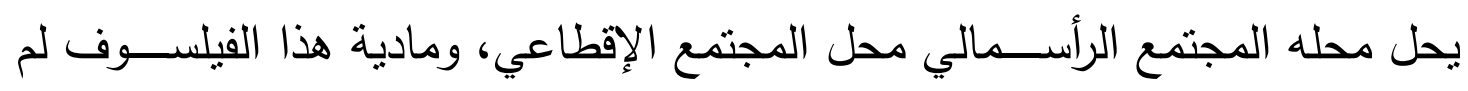

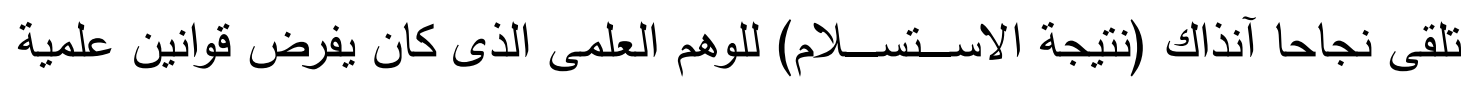

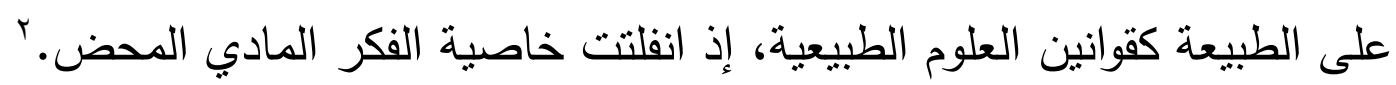
لذلك إعتبرت بوادر الفلسفة الفرنسية فى القرن الثنامن عشـر، براجماتية، لأنها

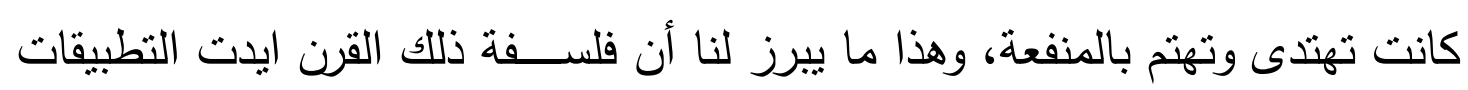
التقنية لا كمعرفة، ولا بغرض استغلال الكون والطبيعة.r

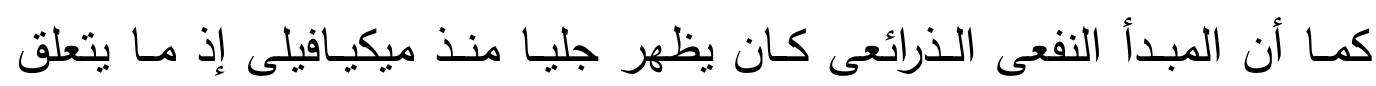

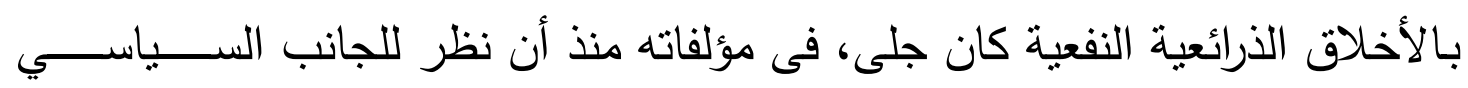

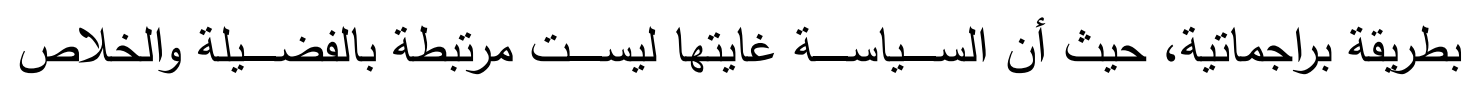

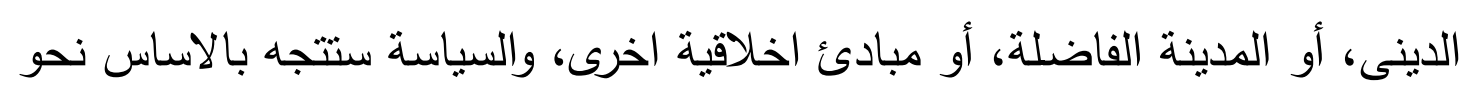

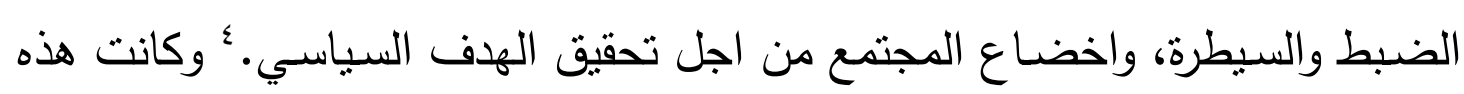

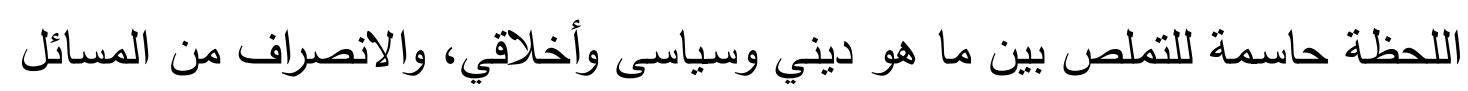

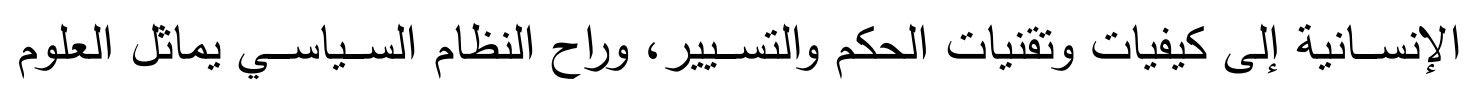

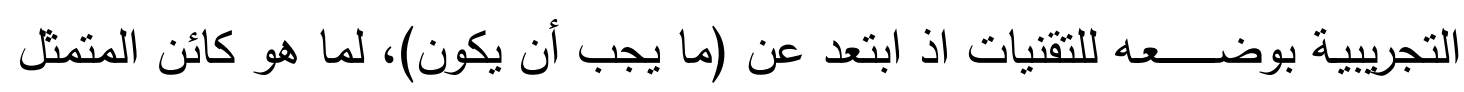
فى تكنولوجيات وقوانين أجتماعية دورها الضبط والسيطرة.

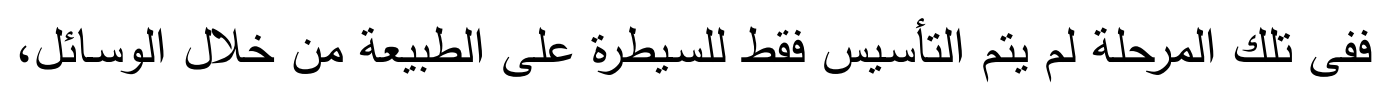

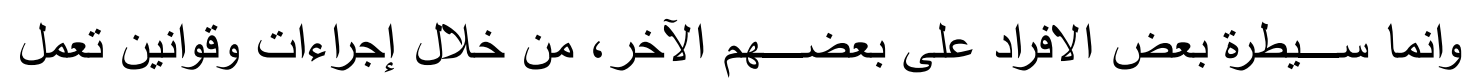
على الهيمنة تشكل ما يسمى بالسياسة.

وعلى مستوى الحداثة الغربية منذ عصر التتوير قامت أسس الفردانية (الأنا)

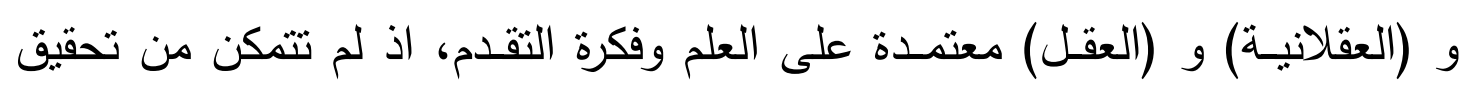

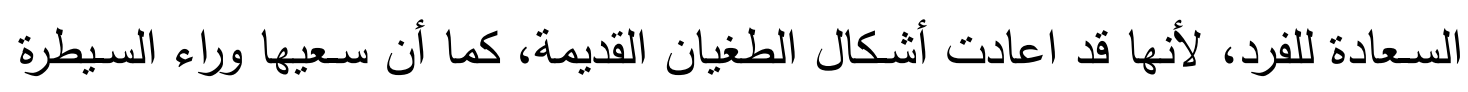

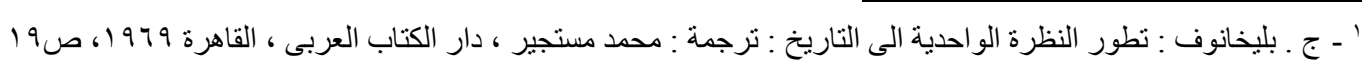

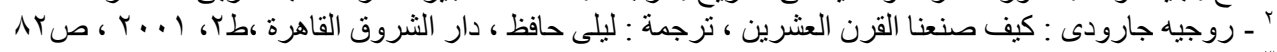

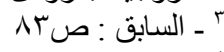

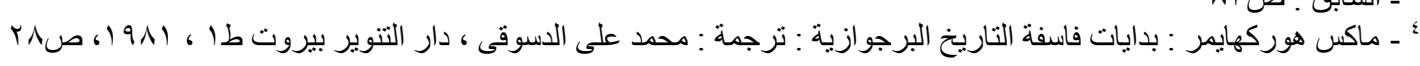


على الطبيعة والافراد هو ما مهز لما حدث على مستنوى الانهيار الحالي للرأسـمالية، و تمثل الحداثة فى القطيعة البطيئة والحتمية بين الفرد والمجتمع والطبيعة.

لذلك فالحداثة هنا تمتل الانفصـــال المتعاظم تدريجيا بين حال الطبيعة التى التى

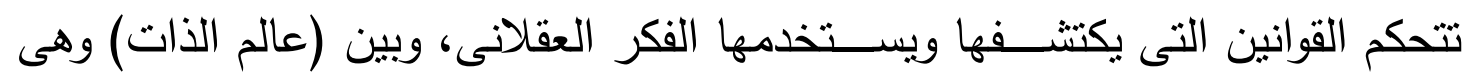

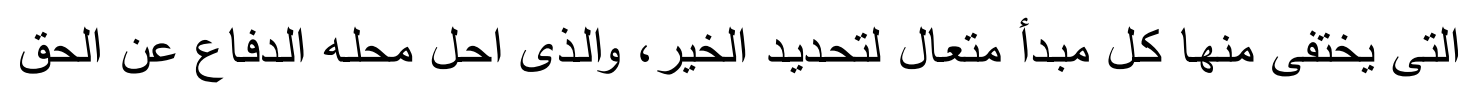

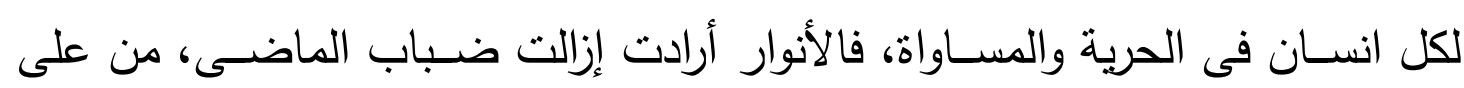

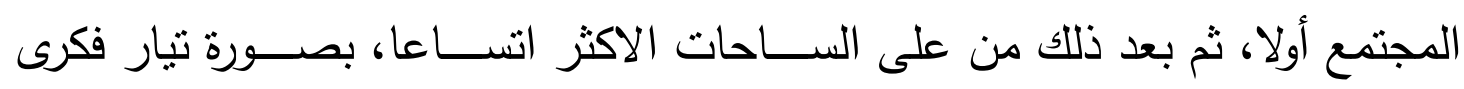

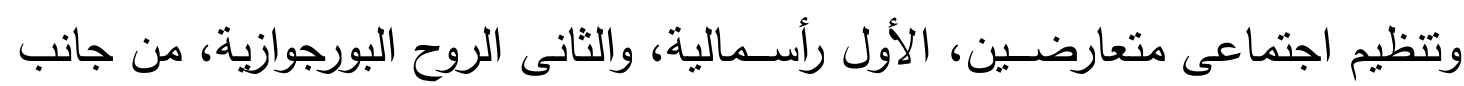

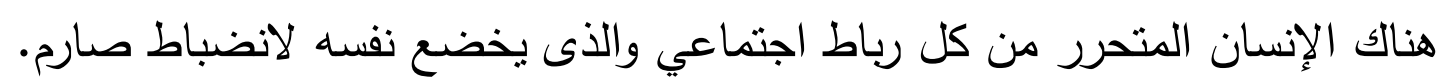

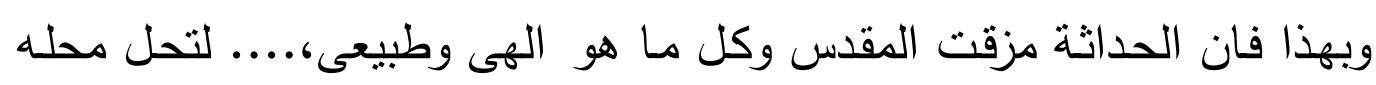

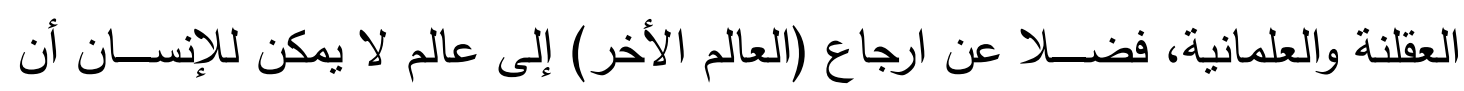

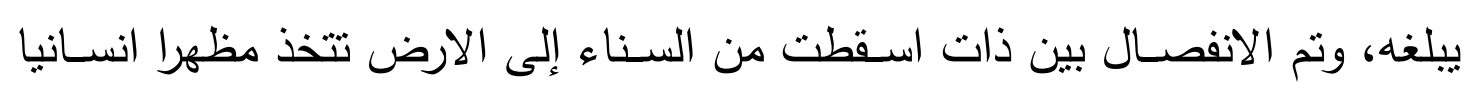

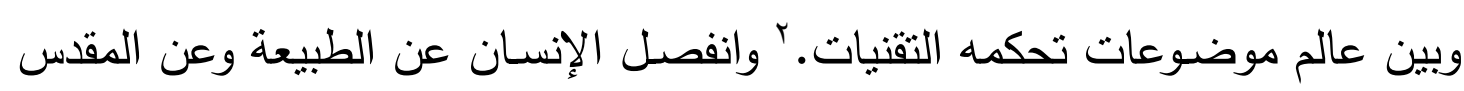

وعن نفسه!

\section{روسو التقدم والاغتراب الإنساني:}

أن الحضـارة الغربية بنيت على أسـس قد تلغى غرائز الإنســان انطلاقا من

$$
\text { السيطرة العقلانية على الطبيعة وعلى الذات. }
$$

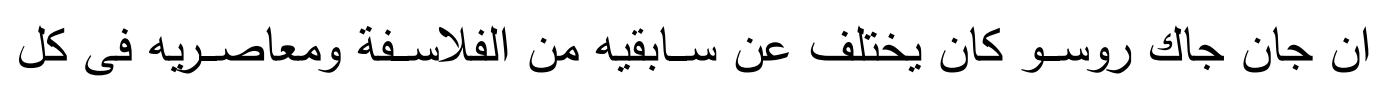

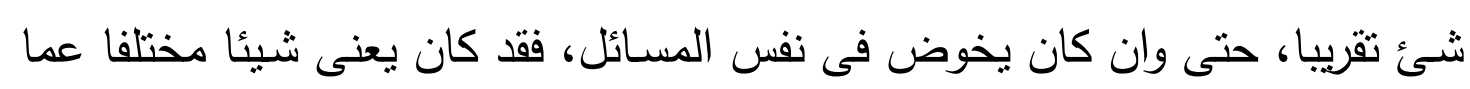

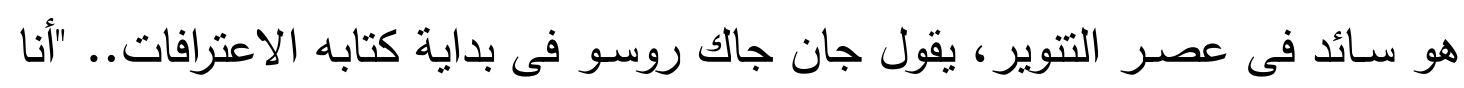

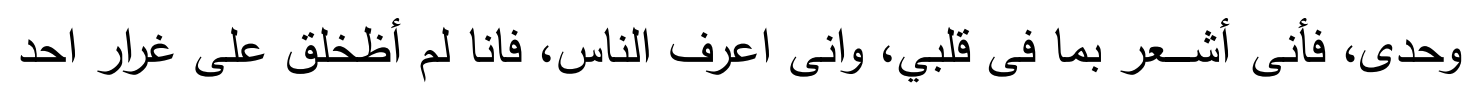

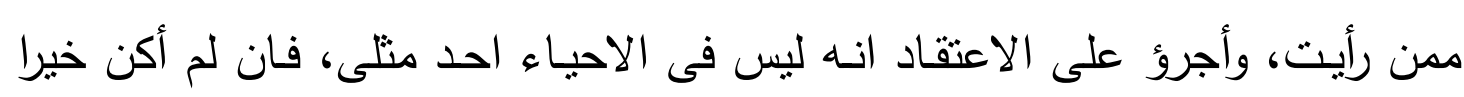

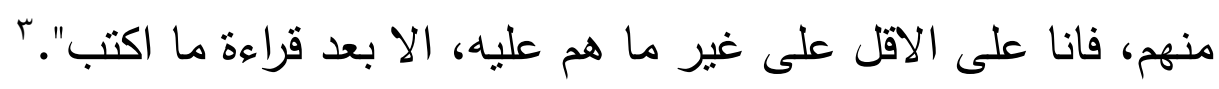

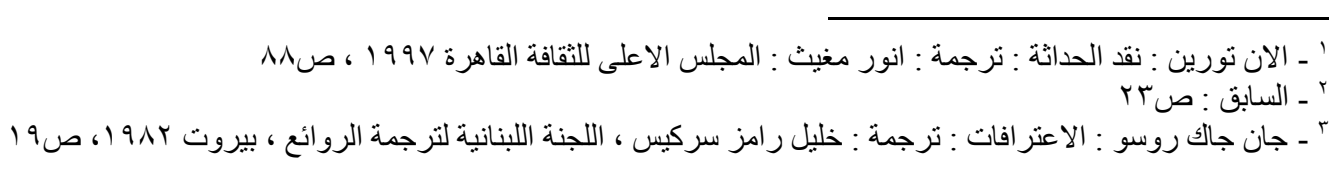


بهذا بدا روسو حركته الفلسفية الجدية كثائر على عقلانية التتوير التى اسست

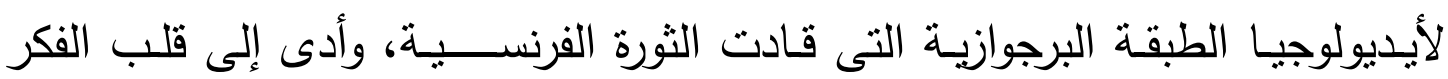
العقلانى فى القرن الثامن عشر وإعادة بناء فلسفة التقافة التتويرية وتغيير مسارها. اول ما اراد أن يؤسـس عليه فلســفته هو أن الطبيعة البشــرية حرة، اما النظام

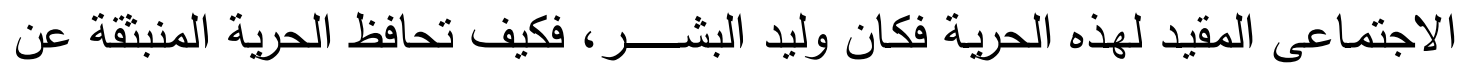
طبيعة الإنسان على نفسها فى المجتمع؟

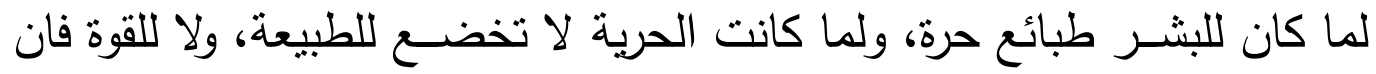

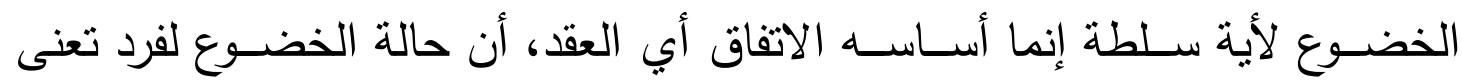

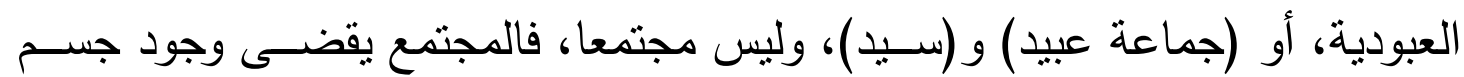
سياسي، والعقد الاجنماعي هو الثرط المالزم للسلطة الثـرعية، والمقدمة الضـرورية لكل نظام سياسى طبيعى.' - ل

يمكننا أن نرى فى مفهوم العقد الاجتماعي سـواء بحضــوره أو بغيابه، انه لا يثــــكل من حيث الجوهر إلا اغترابـا للحريـة الطبيعية، فقى حالة غياب العقد ثــة اغتراب قسرى، وفى حالة وجوده ثمة اغتراب طوعى، ثم وجود الضرورة فى الحالتين: الأولى ضرورة الرضوخ للتعسف الخارجى والثانية الحفاظ على المجتمع. والاغتراب الطوعى بنطوى على اســتعادة الحرية الطبيعية فى شـــل جديد هو (الحرية المدنية) والمسـاولة الضـائعة تسـتعاد فى شكل مسـاواة أمام القانون، ذلك أن

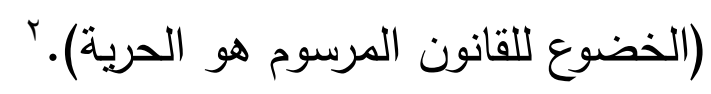
يفترض جان جاك روسو وجود حالة طبيعية فى البشر حيث يعيش الإنسان مع

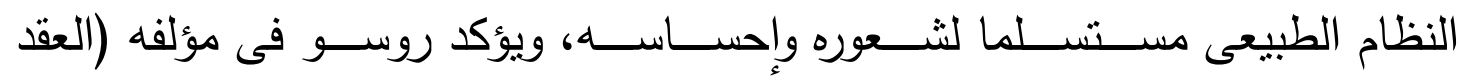
الاجتماعى) ولا الإنســـان حراً طليقاً، وهو فى كل مكان مكبلا بالقيود، فواحد يعتقد نفسه سيداً للآخرين، ولكنه اشد عبودية منهم. الإن 
الإنسـان عند روسو، لا يمكن أن يكون إنسـانا طبيعيا الا فى ظل الحرية، وعند

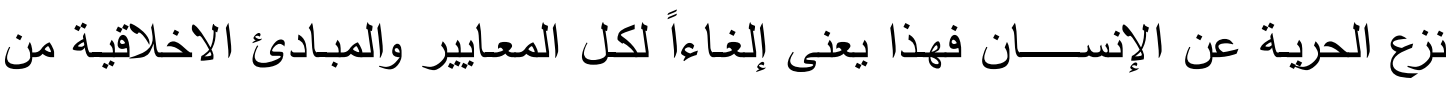

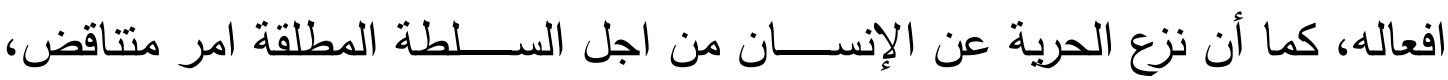

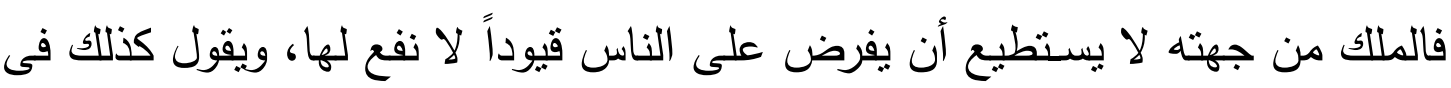

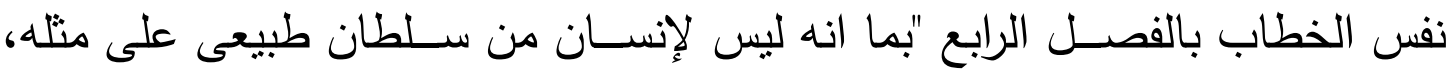

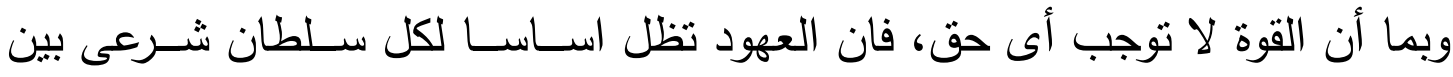
الناس، ومن قول غروسيون أن الفزد اذا كان يستطيع بيع حريته فيصبح عبدا لسيدا،

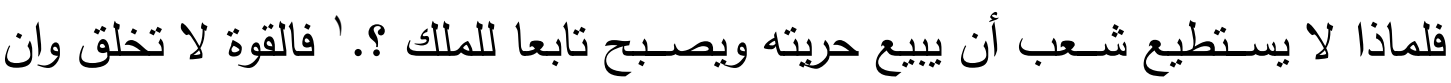

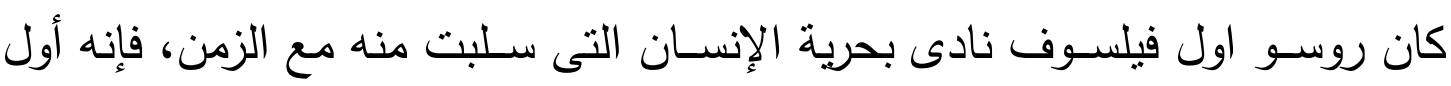

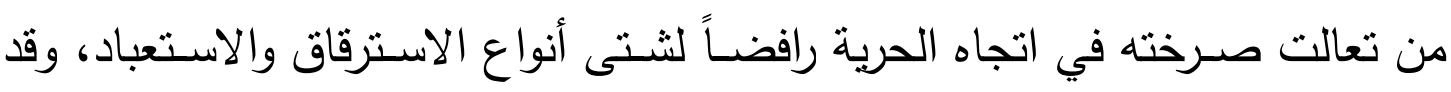
رفض كل نلاك الآراء التى تؤكد على سـيطرة بعض البثــر، وأن البعض منهم (عبيد)

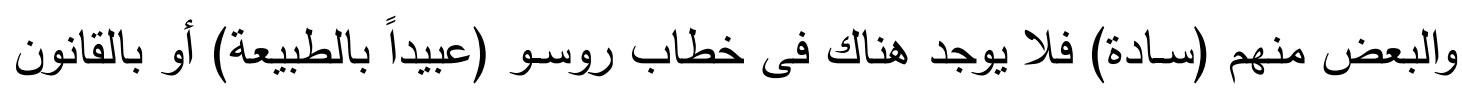

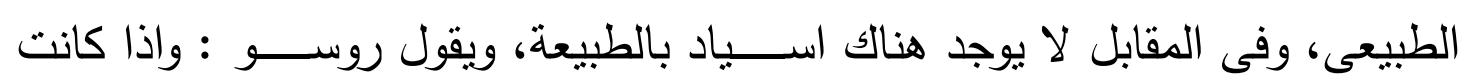

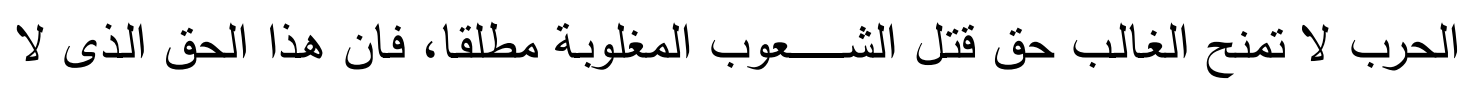

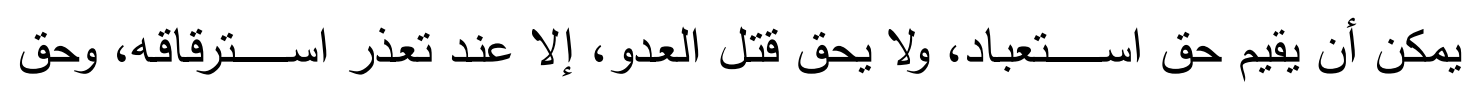

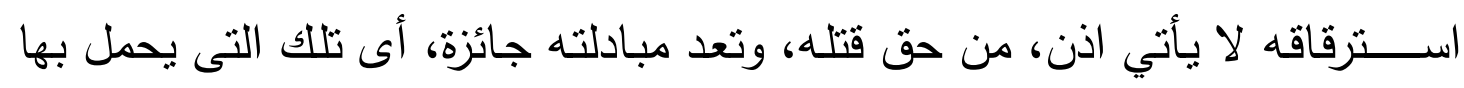

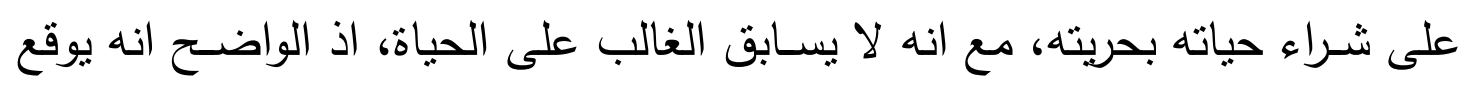

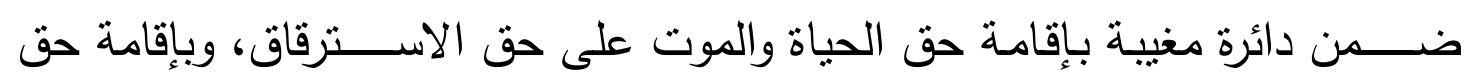

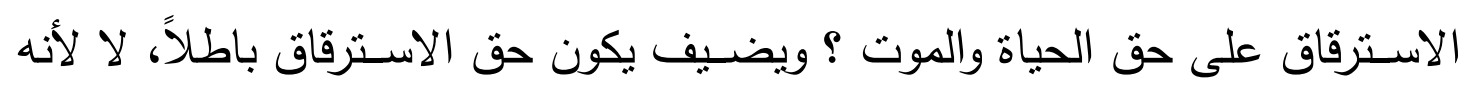

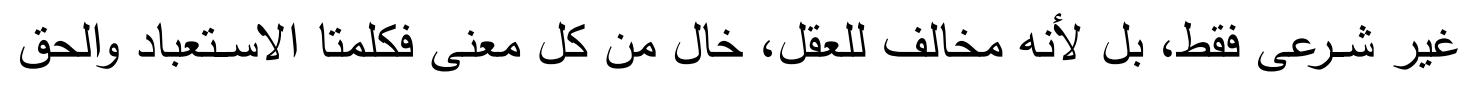

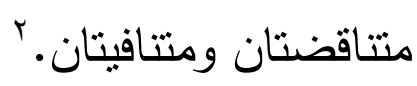

ويتفق روسو فى كتاباته المبكرة مع من سبقوه من فلاسفة العقد، فى استخدامه

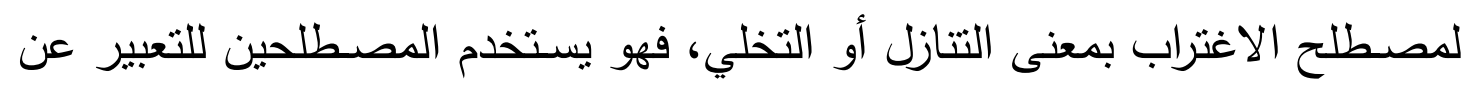

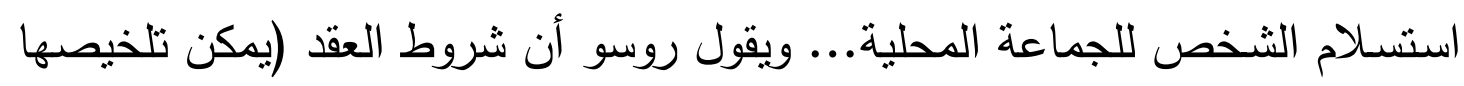


فى نهاية المطاف فى شـرط واحد، هو التتازل الكامل من جانب كل واحد عن جميع حقوقه للمجموع بلا أى تحفظ).' كما يستخدم روسو مصطلح الاغتراب بمعنى يعطى أو يبيع، ولهذا يؤكد روسو بهو

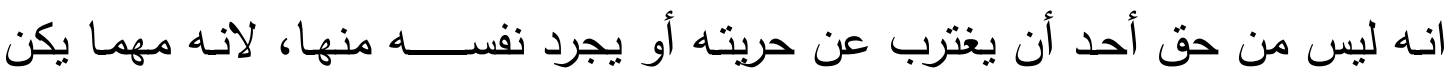
التعويض الذى قد يناله مقابل ذلك فانه لن يكون عوضاً عن الحرية التى لا يعوضهها

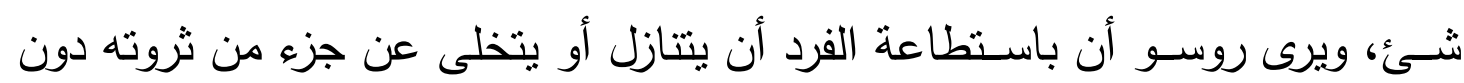

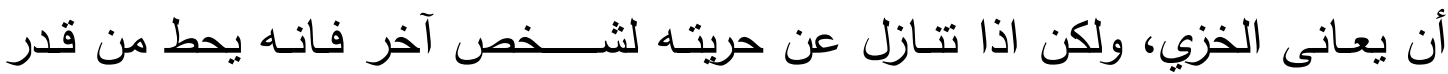
وجوده. ץ اما فى حالة تحويل السـيادة إلى سـلطة جماعية فى إطار المسـاواة الكاملة

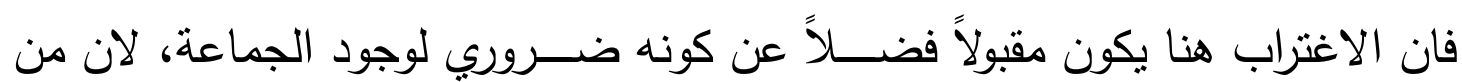
يهب نفسه للجميع لا يهب نفسه لأحد.

وتمنل دراســة روسـو لظاهرة الاغتراب أنضــج دراســة للظاهرة فى الفلسـفة السياسية.

ويرى فرانك جونسـون - بحق - أن مفهوم الاغتراب يتحول من خلال (كتابات)

روســو إلى مفهوم اجتماعى، فقد ارتكز فى تحليله وتقســيره على علاقة الإنســان

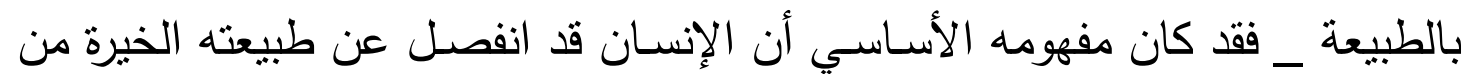
خلال الحياة فى وسط اجتماعي مصطنع وليس من خلال السقوط.

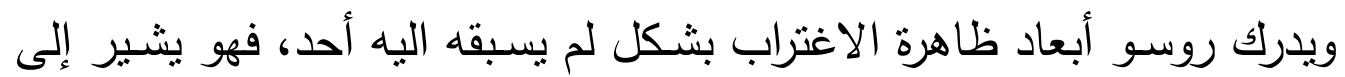
اغتراب الإنســـان عن الطبيعـة. هذه الفكرة التى تبدو فى نقده الاجتمـاعي لمجتمع المدينة فيقول.... "المدينة تفســ الإنسـان، تفصـله عن الطبيعة، ففى عملية التمدن تسـير البشـرية نحو تصـحيح المجتمع على حسـاب النوع، هذا الثـكل المغترب للنمو الحضـرى ييرز التتاقض بين المجتمع والجنس البثـرى، حيث تصـير حياة الإنسـان المتحضر من العبودية التى يولد ويعيش ويموت فيها".

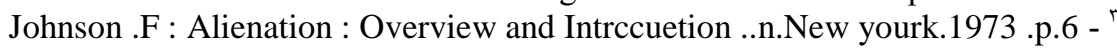

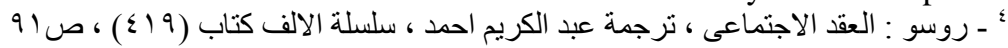


ويشير روسو للأثار السلبية التى تحول الإنسان عن طبيعته الاصيلة، فيغترب عنها، ويتحول إلى انسـان زائف، حيث تسـتبدل دوافعه وعواطفه منذ طفولته بنماذج

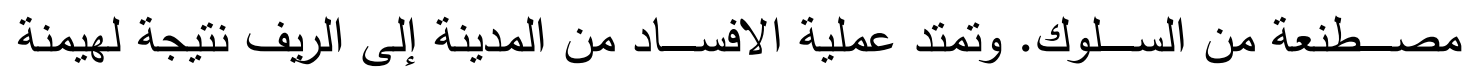

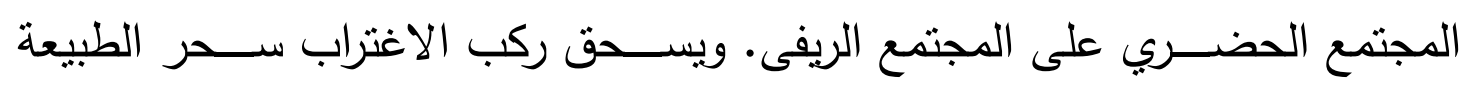
ويكرس التتاقض بين المدينة والريف، حيث تجتذب الصـناعة والتجارة رؤوس الاموال من الريف إلى المدينة، فنزداد المدن غنى ويزداد الريف فقراً.

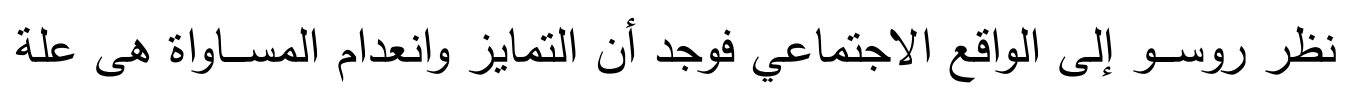

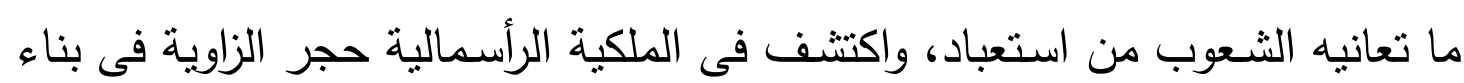
الظلم فى المجتمع. ورأى الحرية فى صميم الطبيعة وفى صميم طبيعة الإنسان، جبل

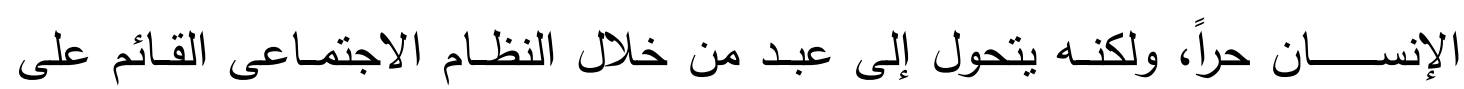
الاســتخلال، الناس يولدون أحراراً، وهم فى كل مكان فى قيود يولدون اخياراً، ولكنهم يتحولون من خلال المجتمع إلى أشرار •

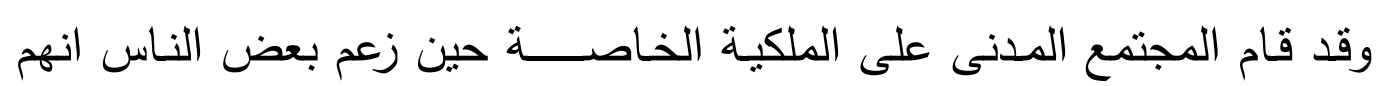

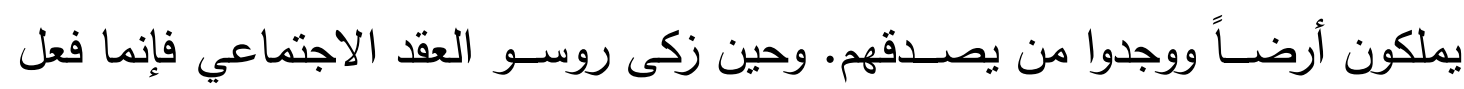

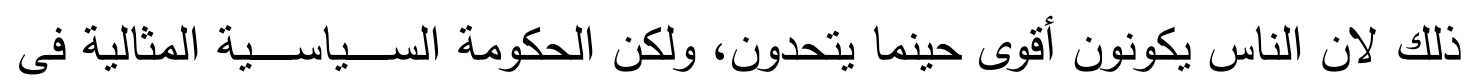
نظره هى التى تمارس الحد الادنى من التدخل، وتترك الطبيعة تمارس عملها. وان

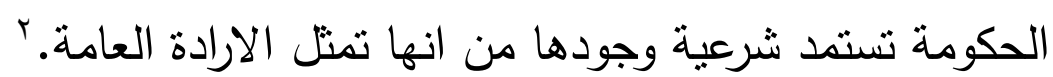

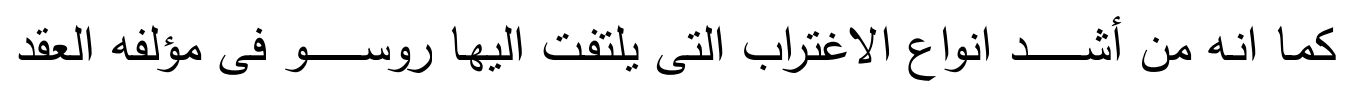

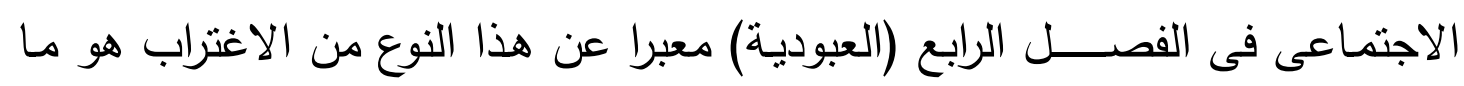

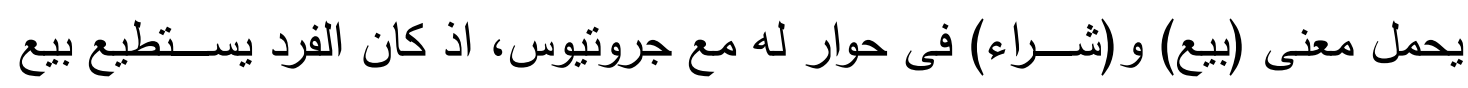

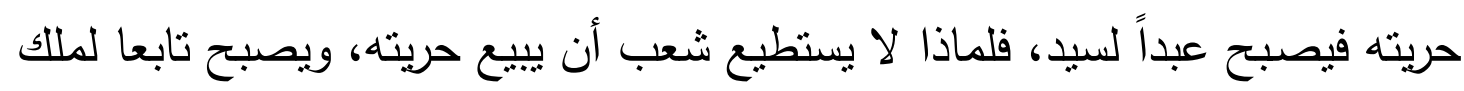

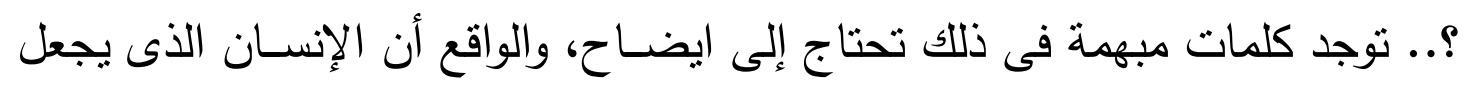

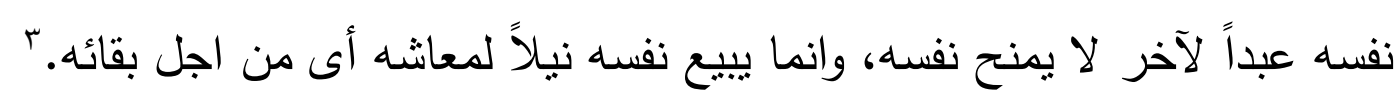


والاغتراب Alienation يحدث فى المجتمع الرأسـمالي حينما تفرض الصــناعة والتقنية سلطتها على الفرد وطبيعته، ويؤدى ذلك إلى احداث فجوة بين انسـان المدينة وانســان الريف، الإنســان البدائى والإنســان التاريخى، وكان هدف روســو هنا هو القضاء عن ما ينتج عن ذلك من شرور، والحل الوحيد هو التتازل عن التحضر لان لان

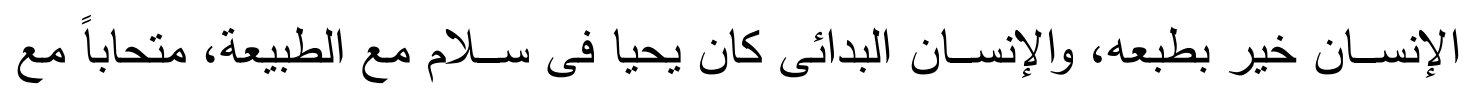
جميع الكائنات.' وعـادة مـا تحدث العزلـة أو الغربـة عن الاخرين بطريقتين: الأولى أختيـاريـة،

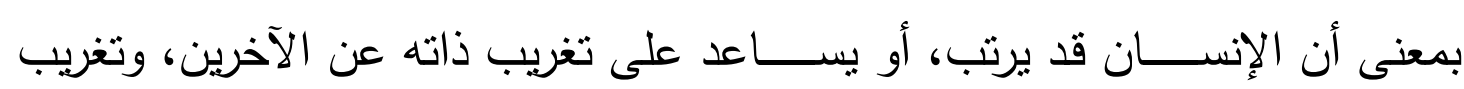

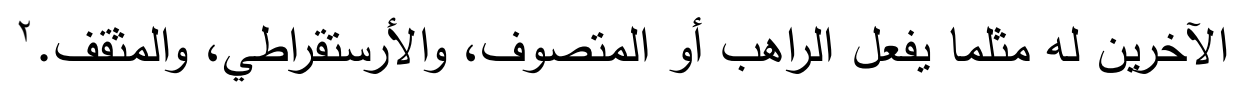

\section{موقف روسو من الطبيعة والحضارة:}

لقد صــب روســو كل اهتمامه نحو اسـتيعاب وفهم الصــفات الجوهرية التى رونى

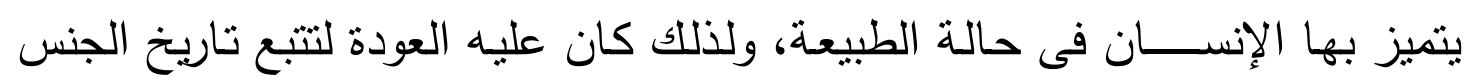
البشـرى لمعرفة كل ما هو مصـطنع ومضـاف إلى الطبيعة الاصـيلة بفعل الحضـارة والتاريخ، ويقول روسو فى خطابه أصل التفاوت بين الناس "لكننا ما دمنا على جهلنا

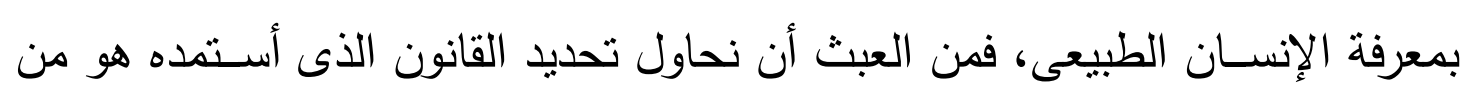
الطبيعة، أو ذلك الذى يلائم تكوينه أكثر من غيره.

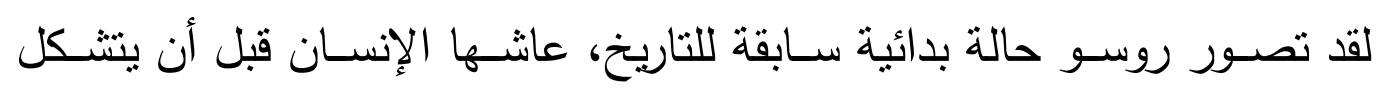
المجتمع البثـرى، وان كان روسـو قد اعترف فى خطابه اصـل التفاوت بين الناس،

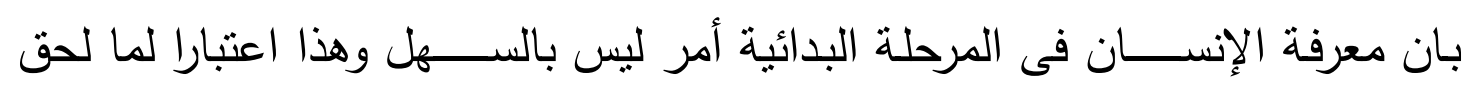

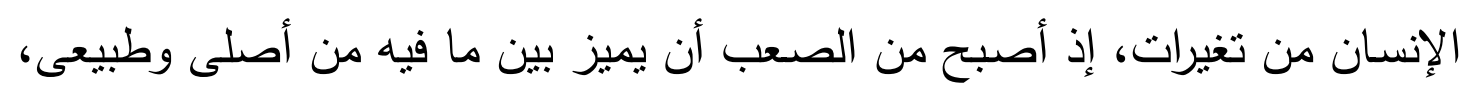

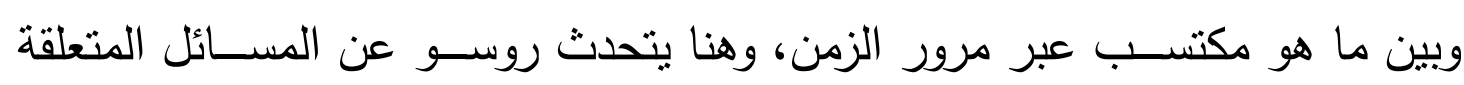

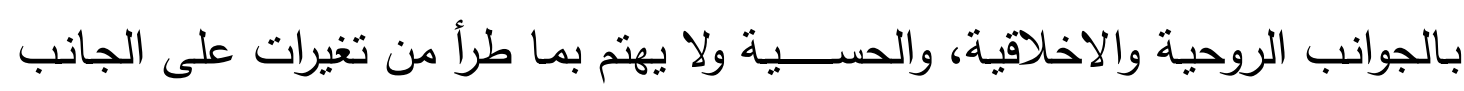

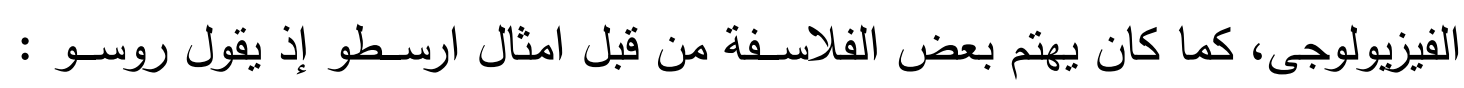

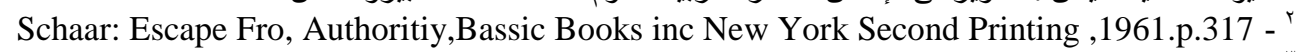

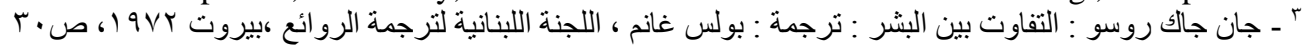


لن أتتبع مراحل بنية الإنســـان فى مراحل نموها المتعاقبة... لن أبدأ بالبحث فى

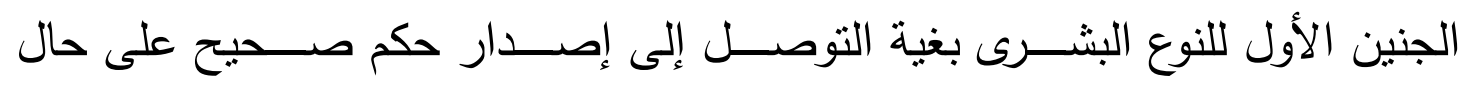

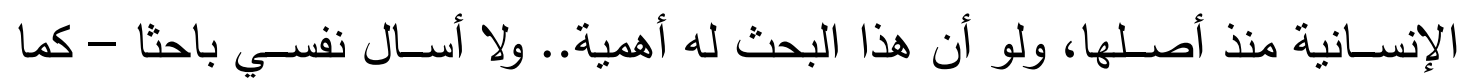

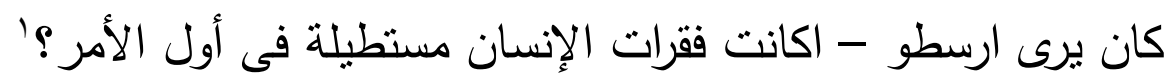

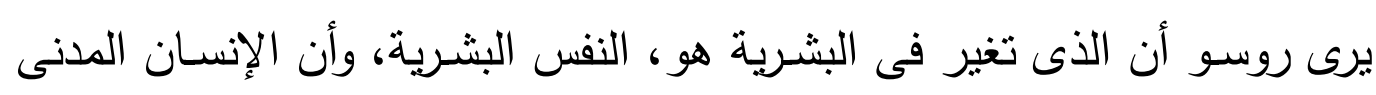

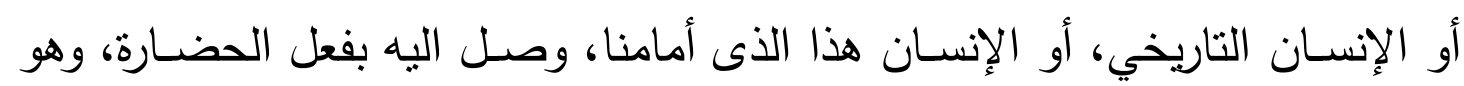

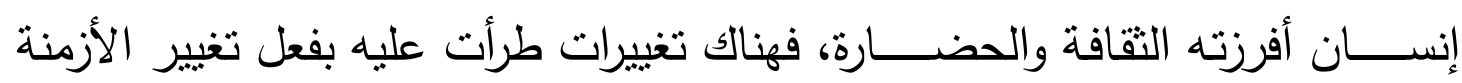

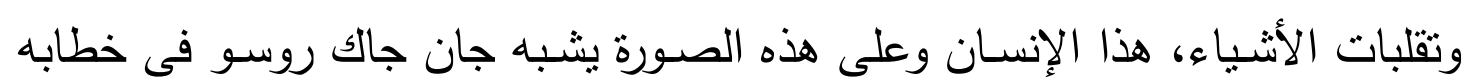

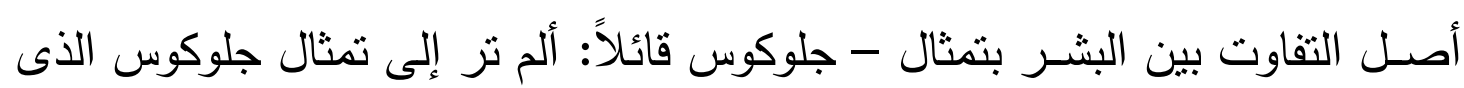

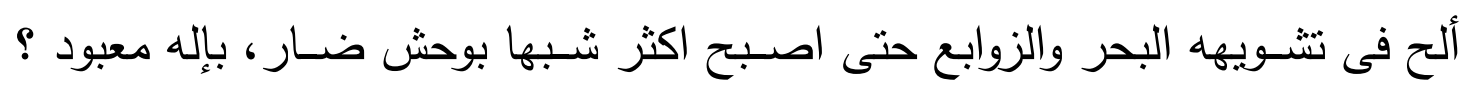

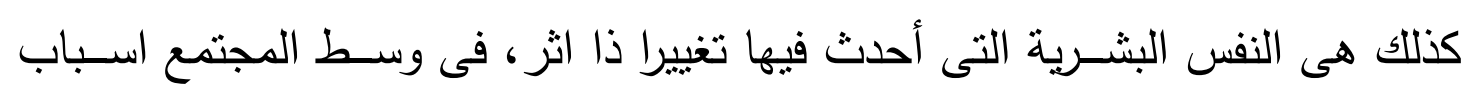

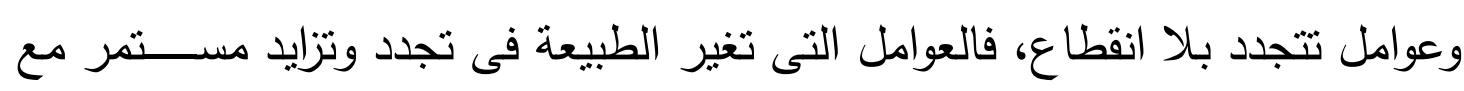
مرور الزمن ومع مواكبة الإنسـان لظروف التحضـر ، إذ راح الإنسـان يفقد إنسـانيته

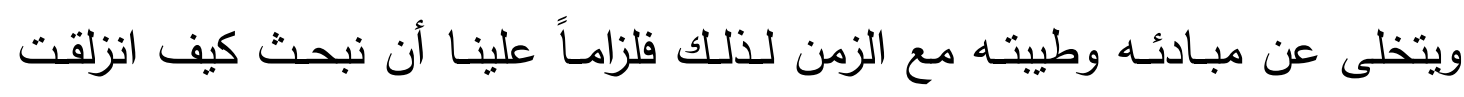

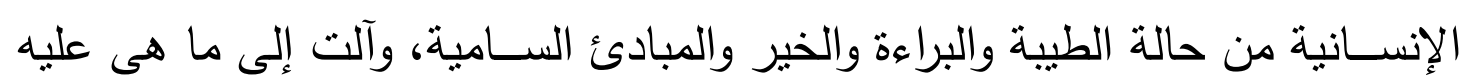
أو صورته النى تنتل الإنسان الددني، التاريخى.

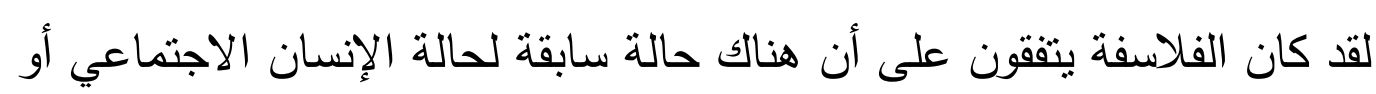

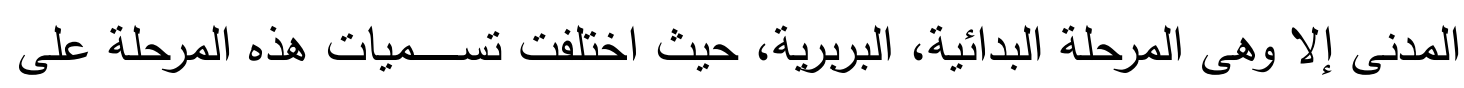

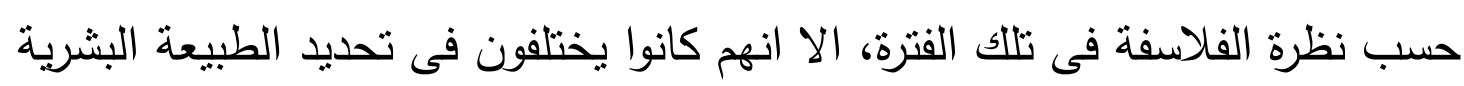
آنذا(ك. فهناك فلاسفة أمثال هوبز مثلا عادوا إلى تلك الفترة من تاريخ البشرية، لكنهم لم

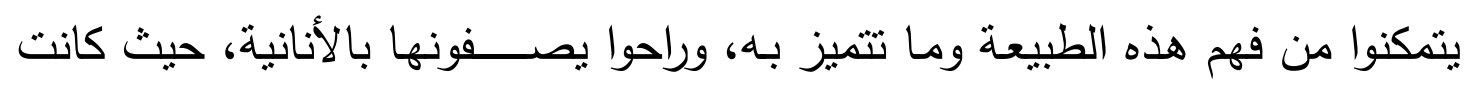

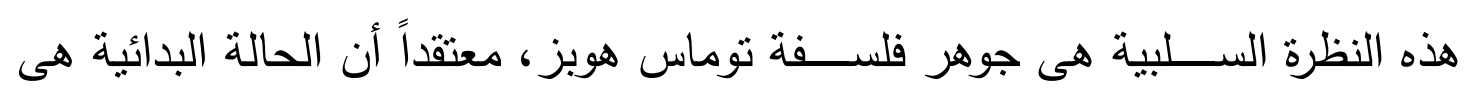

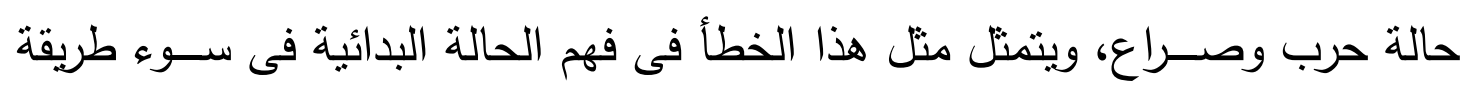


دراسـة الإنسـان، وعدم وصـولهم إلى ما يسـمح لهم بالوصـول إلى ذللك الإنسـان ككل

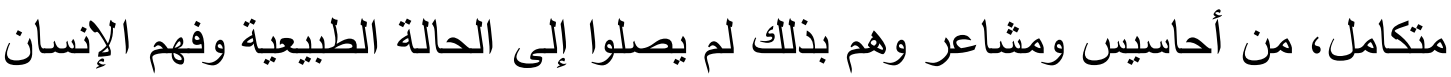
الطبيعى، ونجد روســـو يؤكد على هذا بخطاب أصـــل التفاوت بين الناس قائلا :

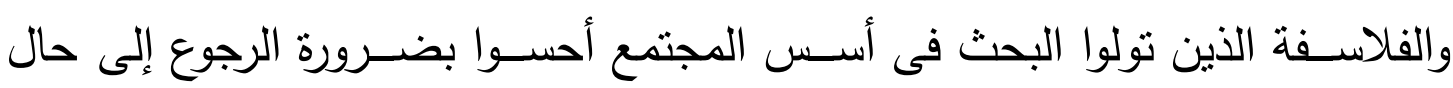

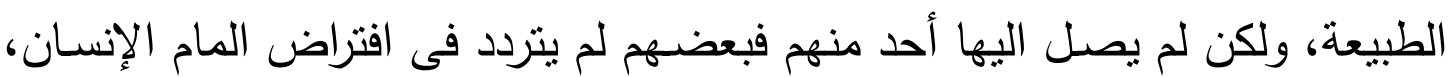

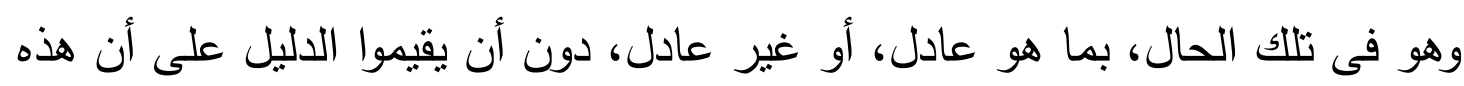

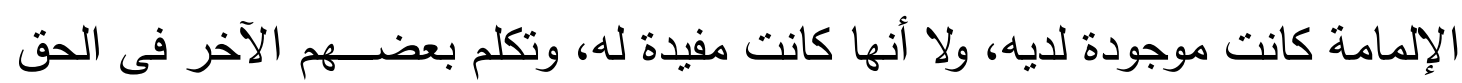
الطبيعى الذى يملكه كل انســان بان يحتفظ بما يخصـــه، ولكنهم لم يبينوا ما يعنونه

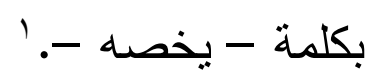

\section{روسو والاغتراب بين الإيجابي والسلبي:}

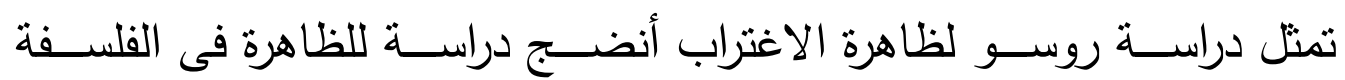
السياسية.

تتاول روســـو الاغتراب بمعناه القانوني فى إطار نظريته فى العقد الاجتماعى وبمعناه النفسى الاجتماعي فى إطار نقده للحضـارة. والفكرة عند روسو ترد بمعنيين،

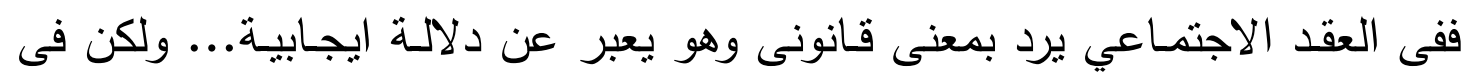

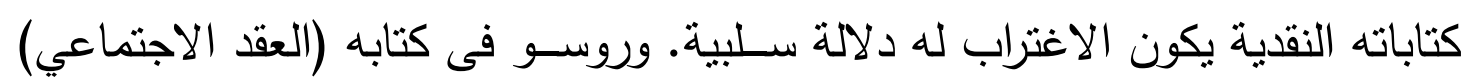
يستخدم الكلمة اغتراب ليصف بها العملية التى فيها يتتازل كل فرد عن ذاته للمجتمع من اجل التعاقد الاجتماعي، يصـــبح داخلا فى الكل. وعلى هذا فأن هذا الاغتراب

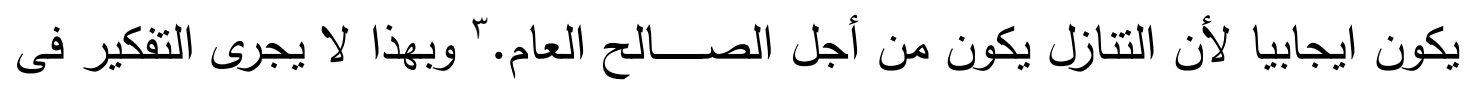

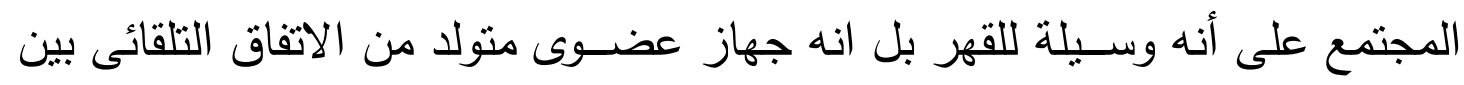
اناس احرار ومتكافئين، انه وسطهم الطبيعى. 
ويتفق روســـو مع هوبز في أن الاغتراب هو عمل أختياري وأن الاعمـال

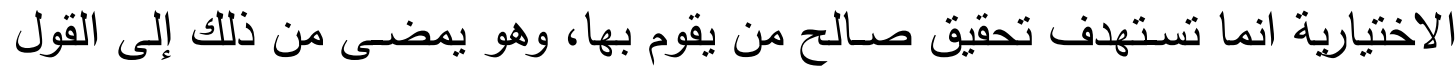

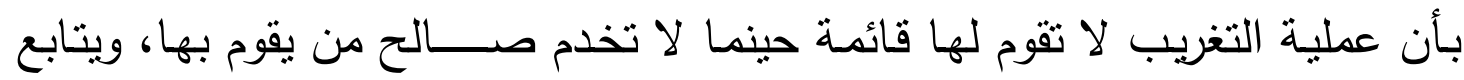

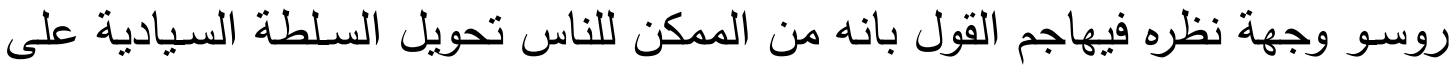
انفســهم لفرد آخر، وكان جروتيوس هو الذى طرح وجهة النظر التى تركز حولها هجوم روسـو، ويذهب روسـو إلى القول بانه ما من شـئ قابل للمقارنة بهذا الذى يتم

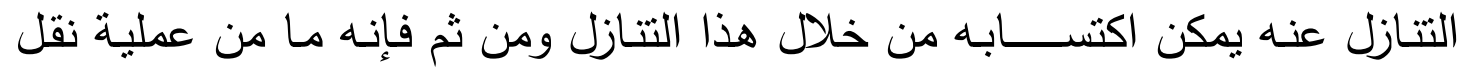

للسيادة بمكن أن تقوم لها قائمة وذلك بغض النظر عن رأى الأطراف المنعاقدة.'

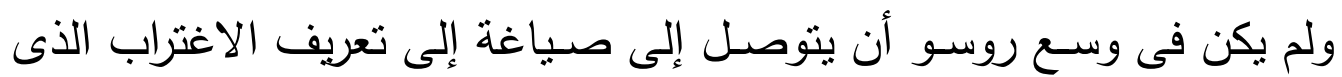

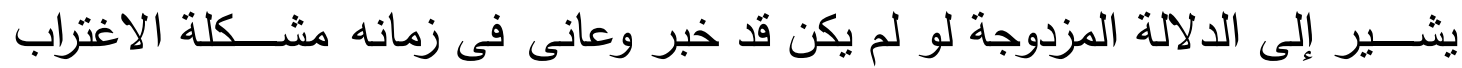

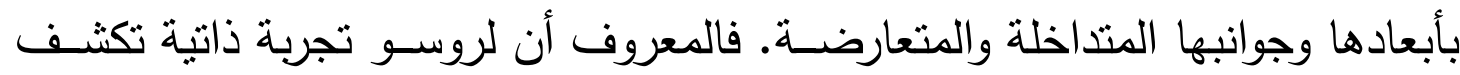
هى نفسها عن موقف نقدي كان قد اتخذه إزاء عصره ومجتمعه وما كان يشيع فيهما من أفكار وقيم زائفة، هذا الموقف الذى يظهر فيه روسـو، أحياناً وكأنه ذلك (الغريب

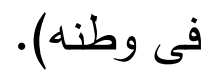
كتب روســو فى اول صــفحة من كتابه (الاعترافات): إنني لأقوم بمحاولة لم

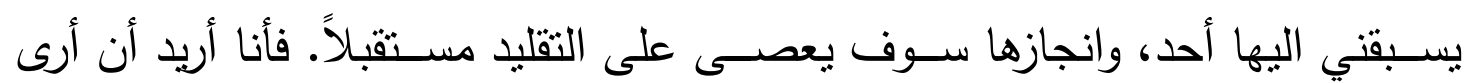

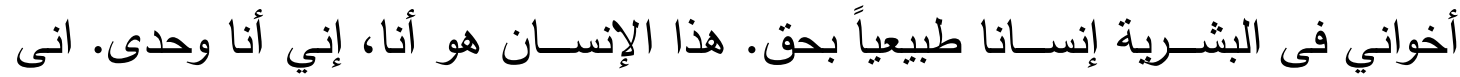

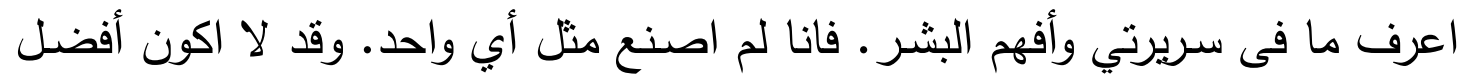

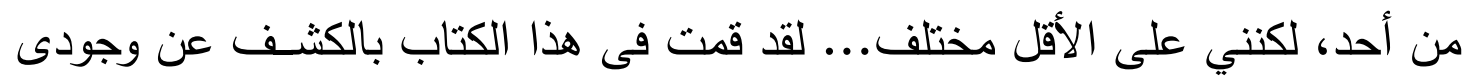

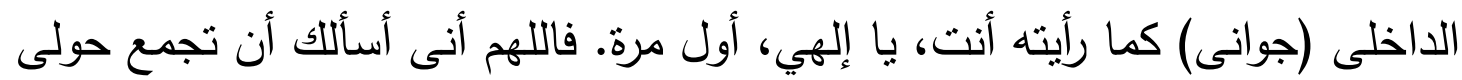

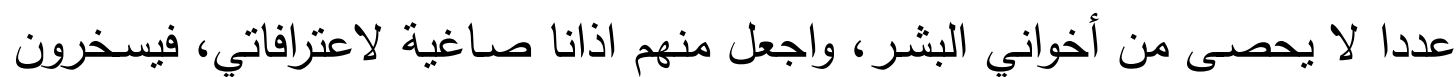
من إهاناتي ويخجلون من خطاياي وفسـي. واجعل كل واحد منهم يكثـف بدوره عنا

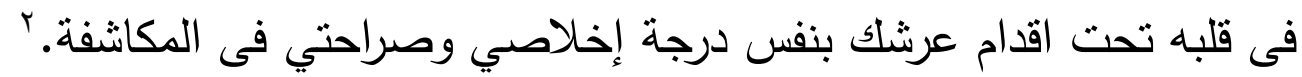


وهناك الاغتراب السلبى وهذا يتضـح فى الكتابات النقدية لروسو وهو ناشئ من الحضارة والمدنية والتقدم والتى افسدت الإنسان فى رأى روسو .

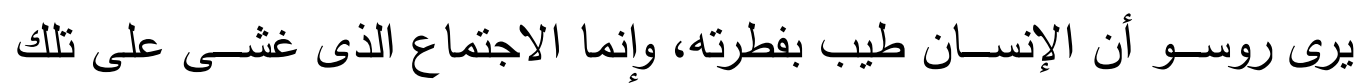

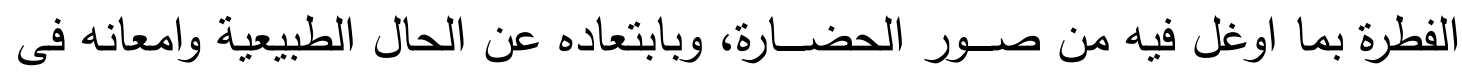
ذلك حتى بلغ غاية التدهور فى القرن الثامن عشر • ولا سبيل لإصلاح هذا الفساد إلا

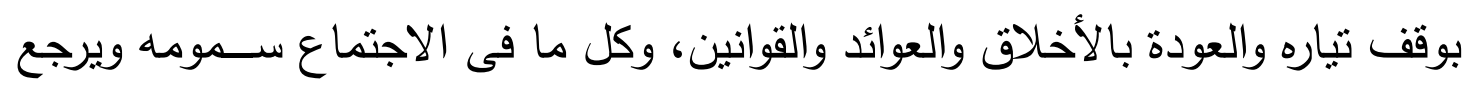
الإنسان طبيا بالطبع كما كان. ' والاغتراب بالمعنى السلبى يتضمن نقطتين: الأولى يرى فيها روسو أن الحضـارة سلبت (غربت) الإنسـان ذاته، وجعلته عبداً خاضــاً للمؤسـســات الاجتماعية التى أقامها، وبذلك لم يعد ذاته وإنما أصـبـح ذاتاً أخرى محددة بشـــل يتم خارج إرادة الإنســان وعلى ذللك يكون الاغتراب هنا مرادفاً

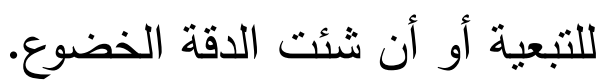
اما النقطة الثانية، فيفرق فيها روسو بين حياتين للإنسان: الأولى: هى حياة التناغم الفطري Original Harmony مع الطبيعة وفيها لم لم روسون يعرف الإنسان الاغتراب.

الثانية: فهى الحياة المدنية الاجتماعية والتى يفقد فيها حالته الأولى، أى يفقد النتاغم الفطرى مع الطبيعة. وهنا يحدث الثقاق بين ما ينبغى أن يكون عليه الإنسان وما هو كائن بالفعل. وفى هذا الانقسـام تكون المعاناة والتعاسـة. ومن هنا خلاف ما

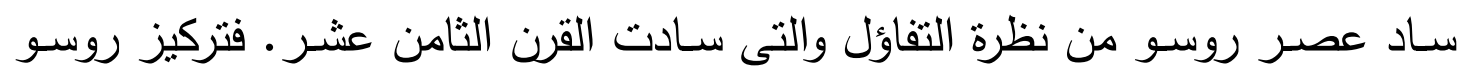

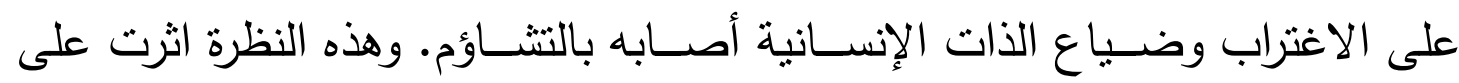

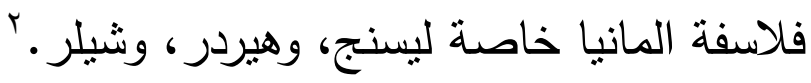
وبهذا يربط روسـو بين مصـادر الاغتراب ومظاهره، فيربط الظاهرة بتركز المال والثروة فى المدن، تلك النظرة لم تكن متاحة لأحد قبله. 
ويتقق فلاســفة العقد الاجتماعي على أن الاغتراب بمعنى التتازل عن الحرية

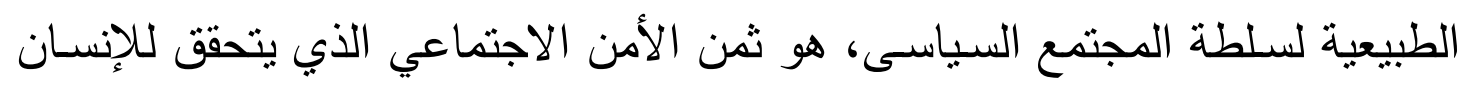

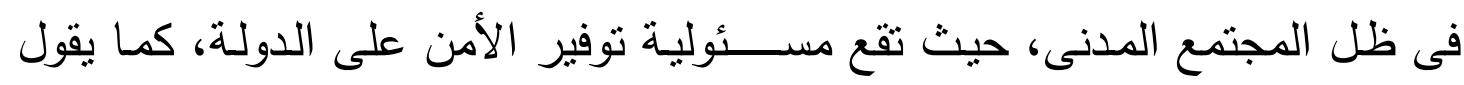

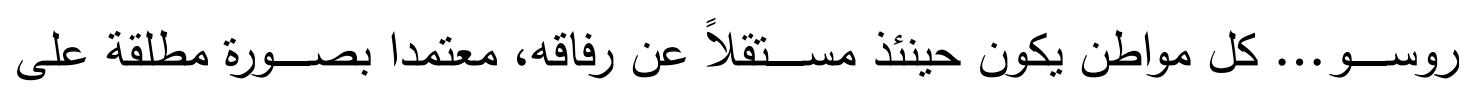
الدولة، قوة الدولة... تؤمن حرية اعضائها. ان هدف الجماعة السياسية الهنظمة هو حماية الإنسان من أى اعتداء محتمل عليه أو على ممنلكاته، وهذه هى الفكرة المحورية فى كل نظريات العقد الاجتماعي.

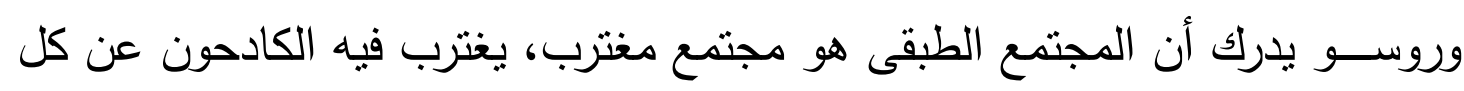

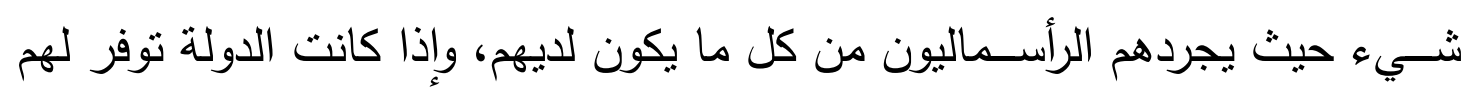

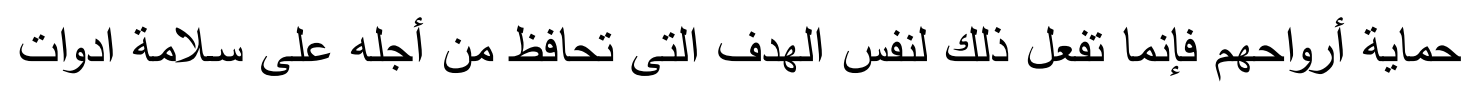

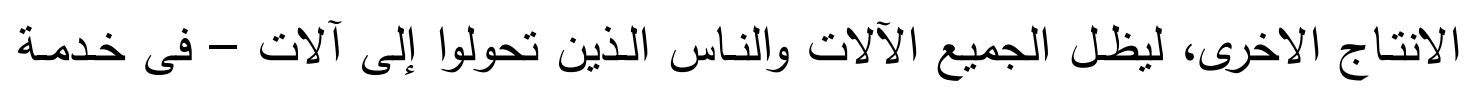

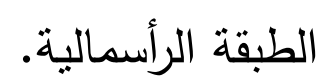

وهكذا نظر روسو إلى الواقع الاجتماعي فوجد أن التمايز وانعدام المساواة هى

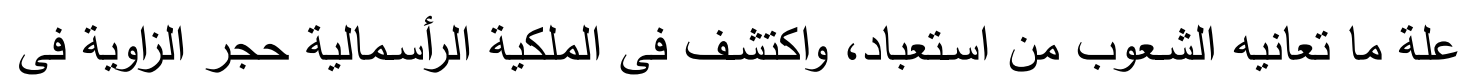

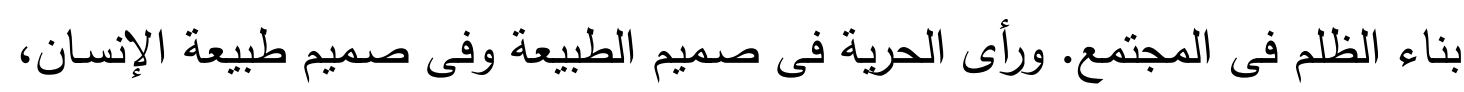

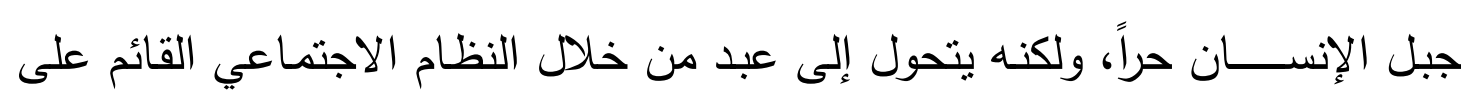

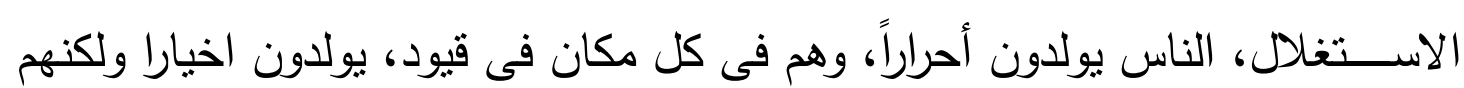
يتحولون من خلال المجتمع إلى أشرار.

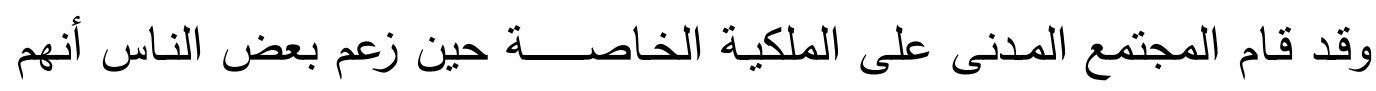

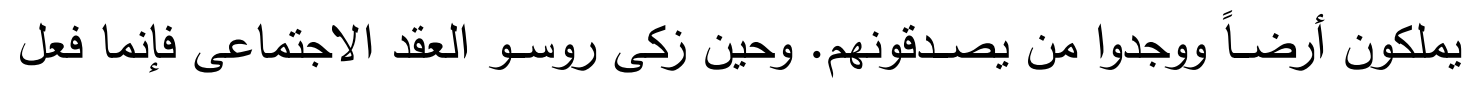

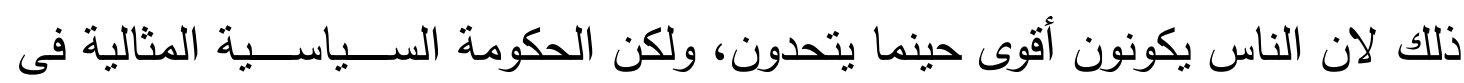

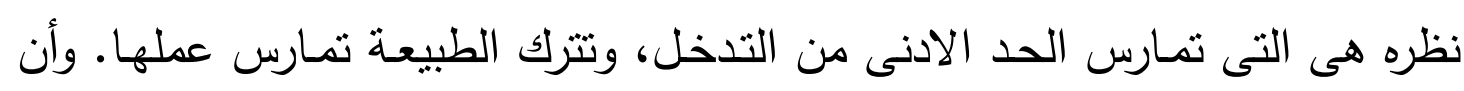

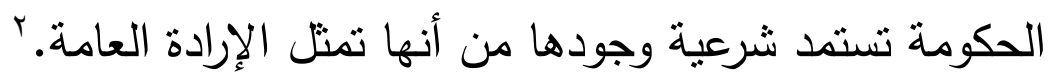
James Bonar : Philosophy and political economy,london george allen,1967,p.187 - ${ }^{r}$ 
يتضـــح الآن أن الاغتراب عند روســو، ذو دلالة مزدوجة: الاغتراب بمعنى

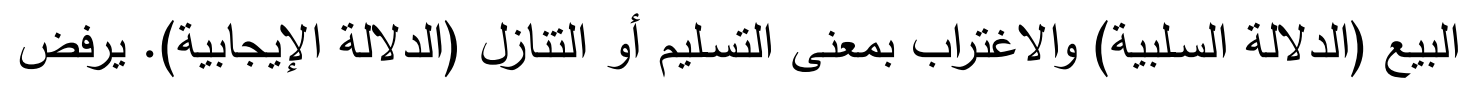

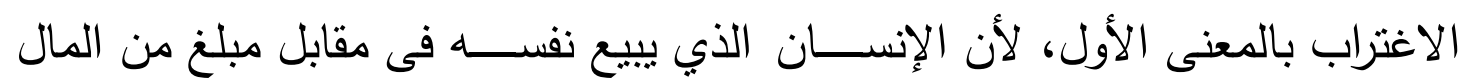

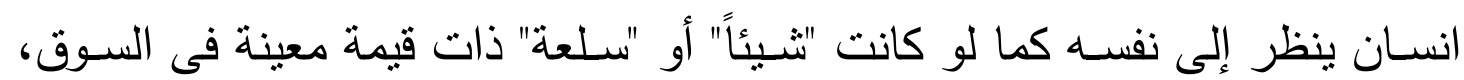

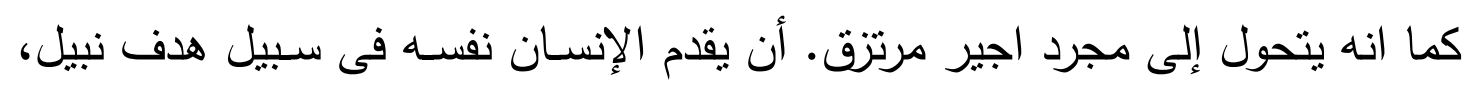

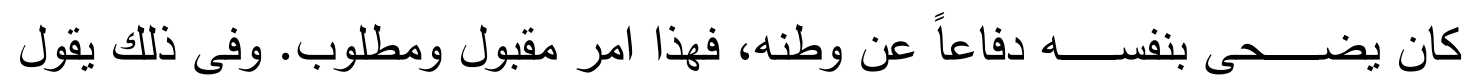

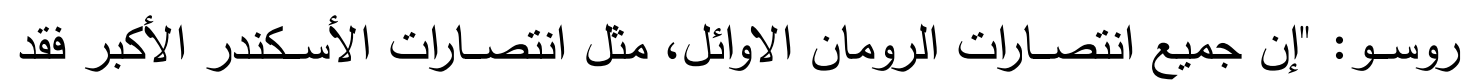

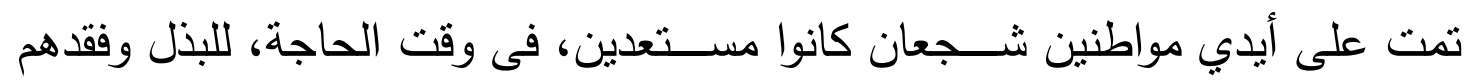

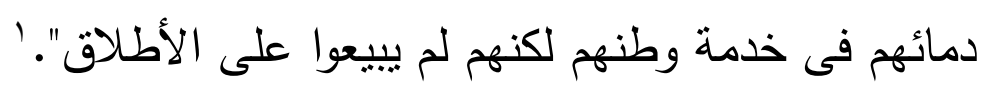

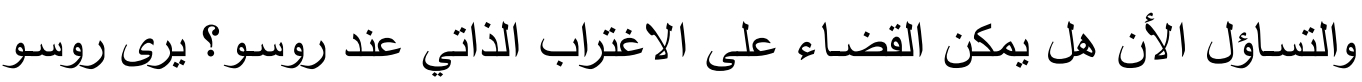

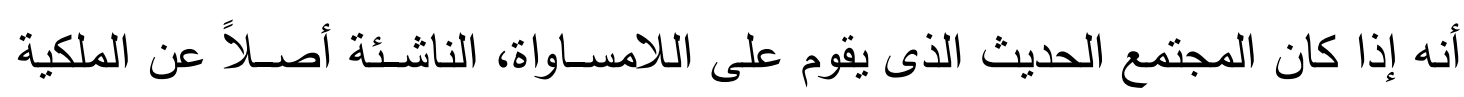

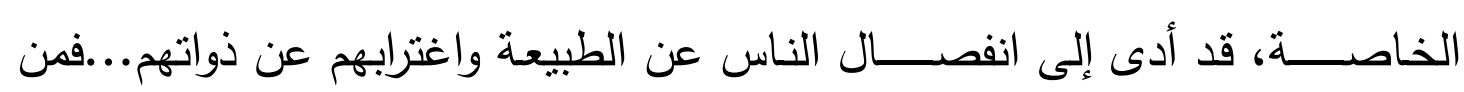

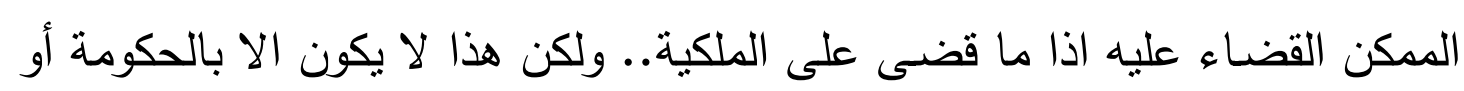

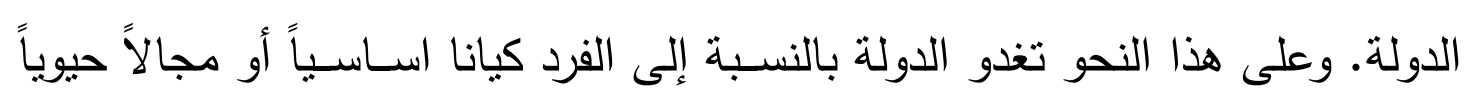
لأغنى عنه.

ويعبر جرودنز عن الاغتراب بأنه الحالة النى لا يثــعر فيها الأفراد بالانتماء

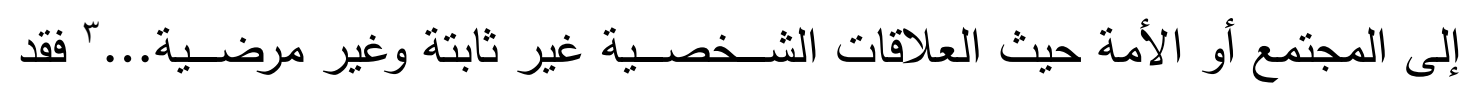

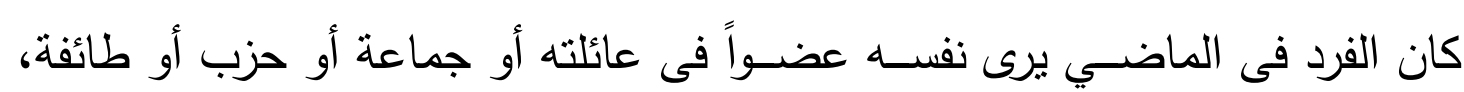

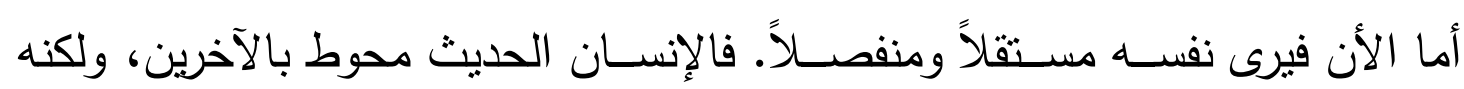

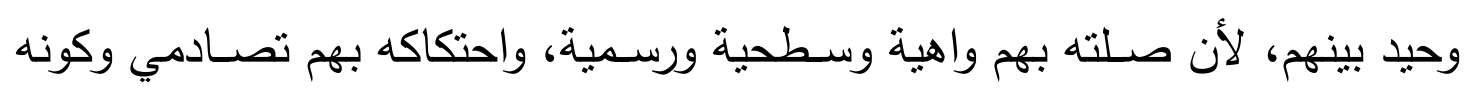

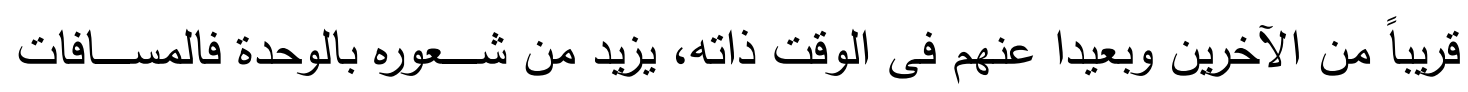

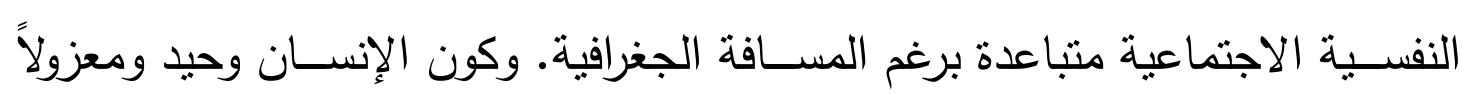
يسهل تغييره وتهديمه، الفرد بمعزل عن جماعته مثل سلحفاة فقدت قنترتها الصدفية.

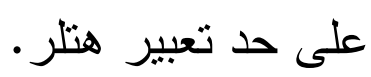
Morton Grodnyins :The loyal and the Disloyal,university of chiccogo press, 1956.p.134 - ${ }^{r}$ 
وهناك تعريف يحدد الاغتراب بـانـه النفور من الذات، بمعنى أن الإنســـان لا لإنهات يستمد الكثير من العزاء والاكتفاء الذاتي من ألوان النشاط الذي يقوم به. ويفقد صلته

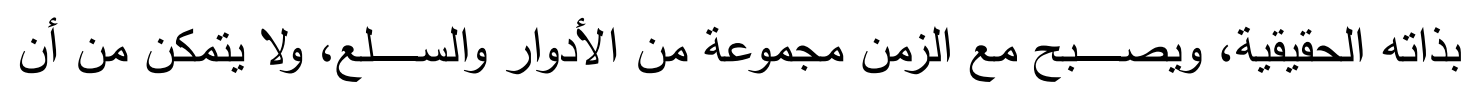
يكون نفسه إلا فى حالات نادرة.' وهذا المعنى يورده فروم يعبر عن صورة العزلة عن الآخرين.. انه شعور بالغربة

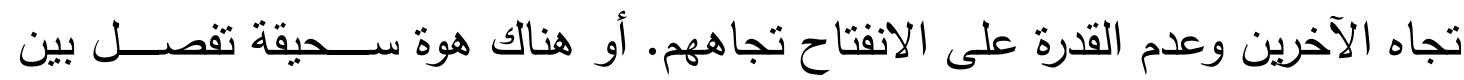

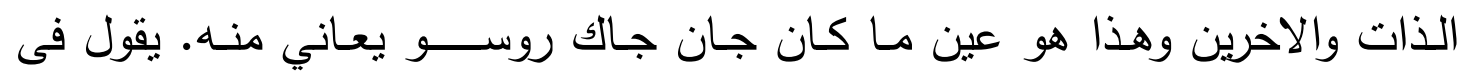
اعترافاته: "لقد كثـــت عن أعمق اغوار نفســي، كما كنت انت تراها، ايها الخالد

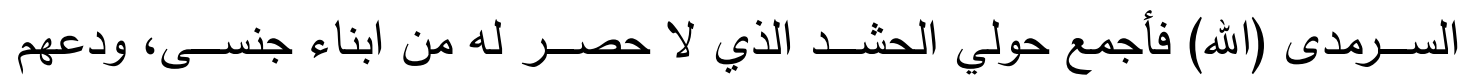

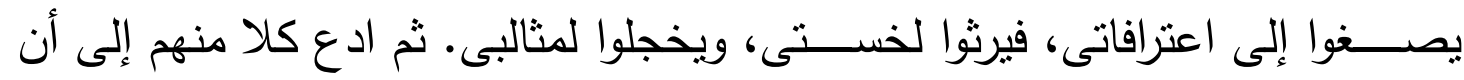

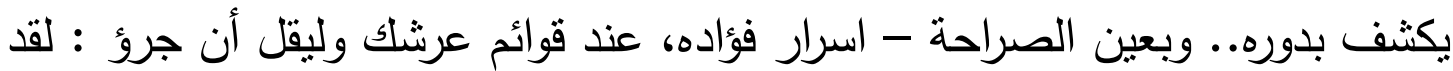

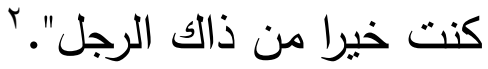
"ولقد كان يمتزج بكل هذا الثُعور بالإشفاق على نفسى، اذ شعرت بأنني أموت،

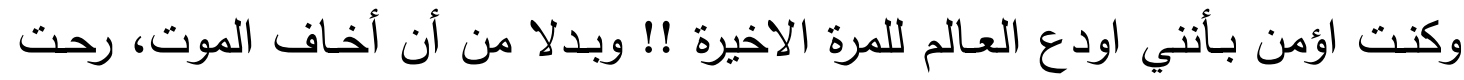

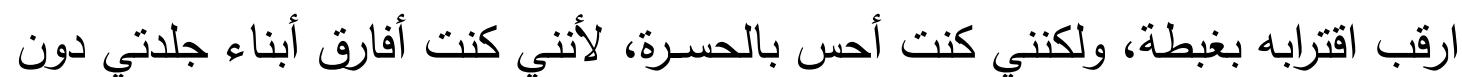

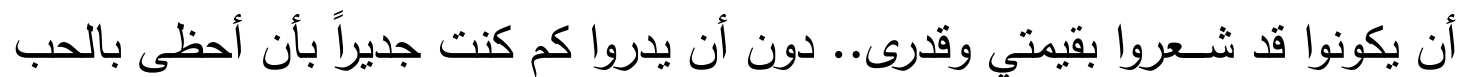
مifم

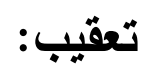

يتبين لنا من خلال موقف جان جاك روســـو من فكرة التقدم، وكيف أن ندعيه من تقدم وتتمية وحضــارة وتكنولوجيا ومدنية... كلها تقف فى وجه الإنســان وتحطم فيه الجانب الإنسـاني... لقد فقد الإنسـان ذاته ودخل إلى مصـيدة الاغتراب.... وراينا كيف تتاول روســو فكرة الاغتراب من الناحية الايجابية والناحية السـلبية، وتعد فكرة الاغتراب عند روسـو من الافكار الأسـاسـية والحيوية والهامة التى يسـتخدمها فى رونى

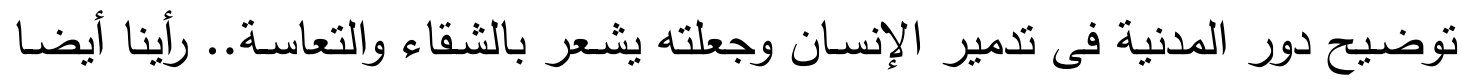


من خلال ما سبق... موقف روسو الهجومى على الدين المسيحى.. فهو يعمل ايضـا على زيـادة العبوديـة والخنوع ويفقد الذات الحريـة... وكل ذللك يعمل على تدمير

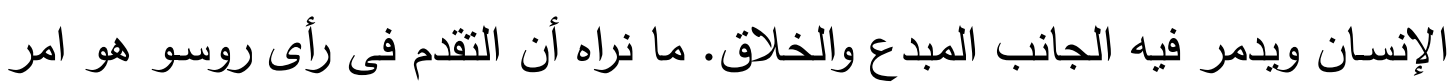

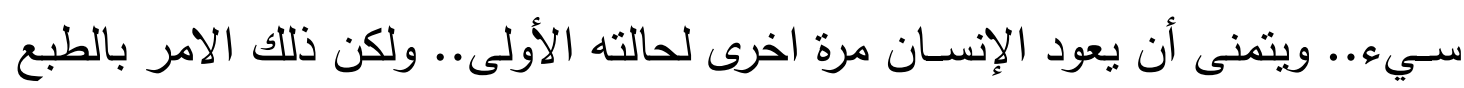

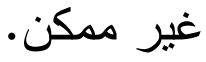

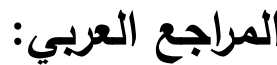

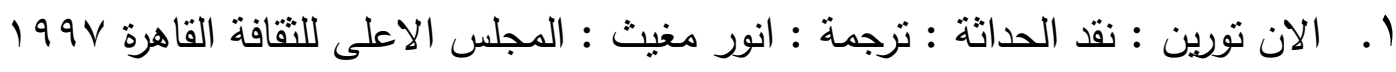
r. اوجست كورنو : اصول الفكر الماركسى، ترجمة : مجاهد عبد المنعم مجاهد، منشورات

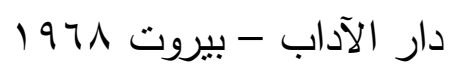

r. بول هزال : الفكر الاوروبى فى القرن الثامن عشر : ترجمة : محمد غلاب، منشورات

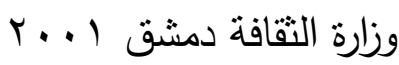
ع. ج. بليخانوف : نطور النظرة الواحدية الى التاريخ : ترجمة : محمد مستجير، دار الكتاب

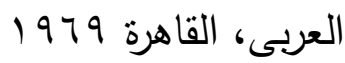
ه.جان جاك روسو : الاعترافات : ترجمة : خليل رامز سركيس، اللجنة اللبنانية لترجمة

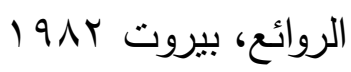
آ. جان جاك روسو : الاعترافات : ترجمة : محمد بدر الدين خليل، طا، 910 الدار

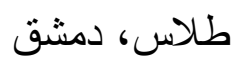
V.جان جاك روسو : التفاوت بين البشر : ترجمة : بولس غانم، اللجنة اللبنانية لترجمة الروائع ،بيروت جVY ^.جان جاك روسو : العقد الاجتماعى ومبادئ القانون السياسى، اللجنة اللبنانية لترجمة الروائع، بيروت جVY 9. روجيه جارودى : كيف صنعنا القرن العشرين، ترجمة : ليلى حافظ، دار الثروق القاهرة

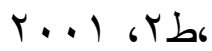
• (1. روسو : العقد الاجتماعى - الفصل الثامن من الكتاب الرابع

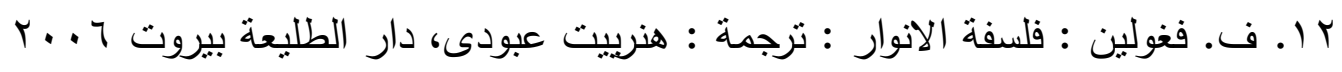

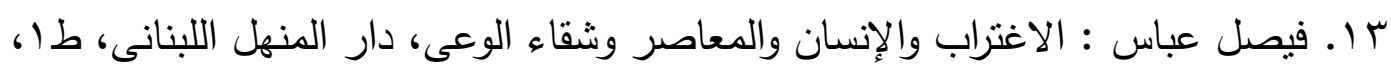

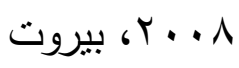


ـ ا ـ ماكس هوركهايمر : بدايات فاسفة التاريخ البرجوازية : نرجمة : محمد على الدسوقى، دار

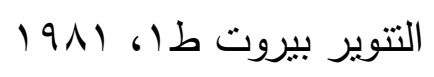

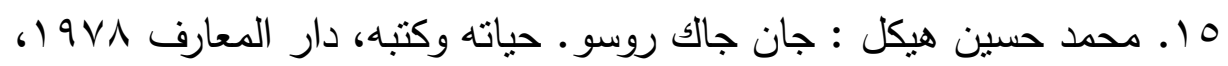

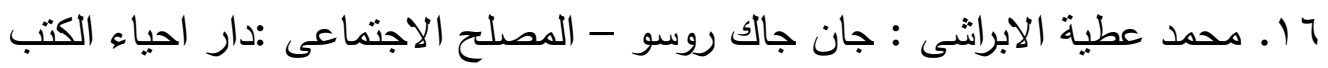

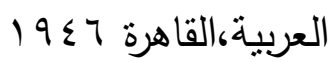

V I ا . محمود رجب : الاغتراب : منشاة المعارف - الاسكندرية، الجزء الاول

19, هربرت ماركيوز : العقل والثورة : ترجمة : فؤاد زكريا : الهيئة المصرية العامة للكتاب

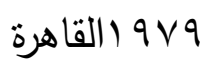

آ. وليم كلى رايت : تاريخ الفلسفة الحديثة : ترجمة : محمود سيد احمد : المجلس الاعلى . بلى

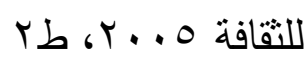

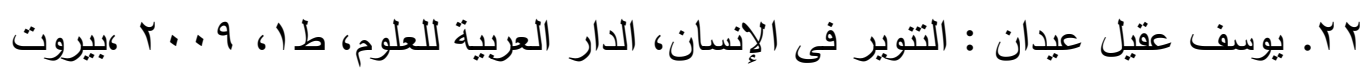

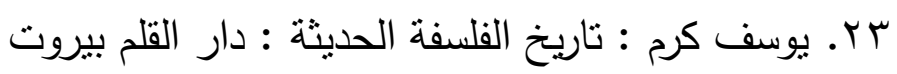

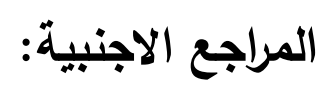

.1 Dunning :political theories : ancient and medieval.book III.

.r E. Fromm : The sane society ،new yourk.1955

.r Hill, Crislopher : Hobbes.T.and the Revolution in political thought.ed.by.jidith N.shklar.Macmillan Company.N.y.1968.

. \& Johnson.F : Alienation : Overview and Intrccuetion..n.New yourk.1973

. R. Nisbet :The Socil philosophers and confliet in western thought,Heinemann,London, 1974

.7 Oskar Schaty and E.F. Winter :Alienation،Marxism and Humanism,(in) Fromm (ed) : Socialism Hummanism Doubledgy \&Company,inc,new yourk،1965

. $\vee \quad$ Rousseau : by Leslie. F. Claydon.

.^ Rousseau; the confessions trans. By،cohen penguin. Book

.9 Rousseau.jj: the social Contract. Trns by. colo.D.H.N.y.1950. 
.1. Schaar: Escape Fro, Authoritiy,Bassic Books inc New York Second Printing،1961.

.1) Schacht : Alienation. George Allen...London.1972 .

ir Stephen Koff :The Political Use of the concept of Alienation.. in Johnson.F.Alienation, new york.1973

ir Torrey,N.L.: Voltaire,Article in "The Encyclopedia of philosophy",vol.8

.) $\leqslant$ W.T.Jones.Mastees of political Thought,Vol.2.George G.Harrap.London.1963. 